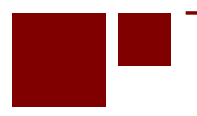

C E N T E R for RETIREMENT

RE S E A R C H

at BOSTON COLLEGE

\title{
THE IMPACT OF MASSACHUSETTS HEALTH INSURANCE REFORM ON LABOR MOBILITY
}

Norma B. Coe, Wenliang Hou, Alicia H. Munnell, Patrick J. Purcell, and Matthew S. Rutledge

CRR WP 2016-16

December 2016

\author{
Center for Retirement Research at Boston College \\ Hovey House \\ 140 Commonwealth Avenue \\ Chestnut Hill, MA 02467 \\ Tel: 617-552-1762 Fax: 617-552-0191 \\ http://crr.bc.edu
}

Norma B. Coe is an assistant professor at the University of Washington's School of Public Health. Wenliang Hou is a senior research advisor at the Center for Retirement Research at Boston College (CRR). Alicia H. Munnell is the Peter F. Drucker Professor of Management Sciences at Boston College's Carroll School of Management and director of the CRR. Patrick J. Purcell is with the Office of Retirement Policy, Office of Retirement and Disability Policy at the U.S. Social Security Administration (SSA). Matthew S. Rutledge is a research economist at the CRR. The research reported herein was pursuant to a grant from the SSA funded as part of the Retirement Research Consortium (RRC). The findings and conclusions expressed are solely those of the authors and do not represent the views of SSA, any agency of the federal government, the University of Washington's School of Public Health, or Boston College. Neither the United States Government nor any agency thereof, nor any of their employees, makes any warranty, express or implied, or assumes any legal liability or responsibility for the accuracy, completeness, or usefulness of the contents of this report. Reference herein to any specific commercial product, process or service by trade name, trademark, manufacturer, or otherwise does not necessarily constitute or imply endorsement, recommendation or favoring by the United States Government or any agency thereof. The authors would like to thank Natalia Orlova for her expert research assistance.

(C) 2016, Norma B. Coe, Wenliang Hou, Alicia H. Munnell, Patrick J. Purcell, and Matthew S. Rutledge. All rights reserved. Short sections of text, not to exceed two paragraphs, may be quoted without explicit permission provided that full credit, including (c) notice, is given to the source. 


\begin{abstract}
About the Center for Retirement Research
The Center for Retirement Research at Boston College, part of a consortium that includes parallel centers at the University of Michigan and the National Bureau of Economic Research, was established in 1998 through a grant from the Social Security Administration. The Center's mission is to produce first-class research and forge a strong link between the academic community and decision-makers in the public and private sectors around an issue of critical importance to the nation's future. To achieve this mission, the Center sponsors a wide variety of research projects, transmits new findings to a broad audience, trains new scholars, and broadens access to valuable data sources.
\end{abstract}

\author{
Center for Retirement Research at Boston College \\ Hovey House \\ 140 Commonwealth Ave \\ Chestnut Hill, MA 02467 \\ Tel: 617-552-1762 Fax: 617-552-0191 \\ http://crr.bc.edu
}

Affiliated Institutions:

The Brookings Institution

Syracuse University

Urban Institute 


\begin{abstract}
This paper examines the impact of the Massachusetts Health Insurance reform of 2006 on job mobility and employment exit using administrative data from the Social Security Administration. The Massachusetts reform mandated that every resident have insurance coverage and facilitated this initiative by requiring employers to offer coverage, as well as expanding Medicaid and creating health insurance exchanges with subsidized premiums. These elements provided the basis for the Patient Protection and Affordable Care Act (ACA) passed nationwide in 2010, so the experience of workers in Massachusetts provides evidence for how the ACA may affect labor market efficiency. Of particular interest is the extent to which Massachusetts' reform reduced “job lock” - the phenomenon in which workers stay with employers to maintain their health insurance coverage, rather than move to a more productive match at another employer (especially a small firm unlikely to offer coverage) or exit employment entirely. The project measures differential effects by age, gender, and firm size, and tries to disentangle the effects of the employer mandate and the individual mandate by identifying individuals who cross state lines between home and work.
\end{abstract}

This paper found that:

- Trend analysis and regression estimates indicate that Massachusetts residents were actually less likely to move to new employers after the reform, relative to workers in neighboring states that did not make structural changes to their health insurance markets.

- Estimates of whether Massachusetts workers moved from large firms, which likely offered insurance, to small firms is statistically insignificant.

- Employment transitions were largely unaffected by the Massachusetts reform, though some select groups saw increases in employment exits that may be consistent with the easing of job lock.

The policy implications of this paper are:

- On the whole, the evidence that the Massachusetts reform increased mobility across employers or out of employment is weak. 
- These findings suggest that either job lock does not tie workers to their jobs as much as labor economic theory had suggested, or that the Massachusetts reform, and by extension the ACA, may not ease job lock as much as some previous research had suggested. 


\section{Introduction}

Reforming the nation's health insurance system has long been on the domestic policy agenda. In 2009, 50.7 million Americans, representing 16.7 percent of the population, lacked health insurance coverage (U.S. Census Bureau 2010). To address this problem, the Patient Protection and Affordable Care Act (ACA) was passed in 2010, based on the Massachusetts health insurance reform enacted in April 2006. The Massachusetts reform package combines (a) an individual health insurance mandate with (b) an employer mandate to offer health insurance, (c) a small-group and non-group insurance market innovation called the Connector, and (d) subsidies to low-income households. The reform has been successful in reducing the number of uninsured - the state's coverage rate for working-age adults increased from 87 percent in 2006 to 96 percent at the end of 2008, and Massachusetts' uninsured rate has consistently been the lowest of any state ever since. The increase for low-income individuals was even more dramatic, from 76 percent to 92 percent insured (Health Connector 2011).

The focus of most research about the Massachusetts reform is on its effects on health coverage and health. ${ }^{1}$ But its effect on labor markets should also be of primary interest. Critics have long maintained that the U.S.’s employer-sponsored health insurance system creates major labor market inefficiencies. In particular, the provision of health insurance by the employer generates some worker-employer matches that are motivated by health insurance as opposed to productivity. The insurance-employer link also discourages the dissolution of inferior employeremployee matches when workers worry about losing employer-sponsored health insurance. This “job-lock” phenomenon affects workers of all ages and can be experienced in a variety of ways, including: distorted retirement decisions; reduced job turnover; lower prevalence of selfemployment; and longer duration and higher prevalence of receiving welfare benefits (Gruber and Madrian 2004).

This study examines the effect of the Massachusetts health reform on job mobility and employment exits. It takes advantage of administrative data with larger sample sizes than are available in public-use datasets such as the SIPP, allowing us to detect the influence of policy on even a fairly low probability event such as a job transition or labor force exit. The administrative

\footnotetext{
${ }^{1}$ For health coverage, see Long (2008) and Long and Dahlen (2014). For the health effects of the MA reform, see Sommers, Long, and Baicker (2014); Miller (2012a, 2012b); Van der Wees, Zaslavsky, and Avanian (2013); Courtemanche and Zapata (2014); and Long, Stockley, and Dahlen (2012).
} 
data also include both the state of residence and the state where the employer is located, so it allows us to separate the effect of the individual mandate-which affects workers who live in Massachusetts, even if they work elsewhere-from the effect of the employer mandate_-which affects employees in Massachusetts firms, even if they commute to the Commonwealth from elsewhere. Using a difference-in-differences approach, this paper assesses the impact of the Massachusetts health insurance reform on job mobility and exits from employment. Our estimates are imperative in helping to understand the as-yet-unmeasured effects of the ACA, seeing as the national, all-at-once rollout of most of the relevant facets of the ACA make evaluating its effects on job mobility hard to identify.

This paper continues as follows. Section 1 discusses the Massachusetts health insurance reform and its potential to ease job lock. Section 2 outlines the model. Section 3 discusses the administrative data. Section 4 presents descriptive statistics, including trends over time in employer changes and employment exit. Section 5 presents regression results. Section 6 concludes that very little evidence exists for the Massachusetts health insurance form easing job lock - at best, some workers were less likely to seek employment at large firms, but most other estimates of the response of job mobility and employment outflows to the reform are statistically insignificant or are inconsistent with the job-lock theory.

\section{MA Health Insurance Reform and Job Lock}

In 2006, Massachusetts passed landmark health insurance legislation-comprised of nonand small-group market reforms, individual mandates, and pay-or-play mandates for employersponsored health insurance-which became the model for the ACA. This reform package increases both the demand for and the supply of health insurance. Demand is increased through the individual mandate and government subsidies that lower the price of insurance. Supply is increased through the employer mandate, if employers increase the offering of health insurance to avoid a penalty payment, and through improving the small- and non-group market. These improvements include: (1) government involvement in setting standard policies (Bronze, Silver, and Gold) and screening companies and their prices; and (2) providing an aggregator internet site (the Connector), which makes it easier to find and compare insurance for individuals not getting insurance through their employer. 
While the Massachusetts reforms maintain the employer-sponsored health insurance delivery system, the increase in the supply of health insurance-either from competing employers or the Connector-could ease the inefficiencies commonly referred to as a job-lock, creating more job turnover. For prime-working-age individuals (age 25-54), the lower cost and increased availability of individual insurance could affect the strength of worker-employer attachments. Workers, who before the 2006 reforms had employer-provided health insurance and did not want to lose it, were locked in their current job; workers subject to the typical notion of job lock should be more likely to change employers after the reform. The reforms, by increasing the demand for insurance, could also increase mobility among workers who previously preferred to go uninsured in return for a higher cash wage. Thus the increased turnover could be between employers or through an increase in self-employment, since the reforms will have decreased the cost of getting insurance through the non-group market. In this paper, we measure the total impact of the reforms on labor market mobility since individual-level information on previous health insurance availability is unavailable.

The Massachusetts health insurance reform may also impact the job mobility of individuals near traditional retirement ages (ages 55-64). This subset of the population could be even more sensitive to the health insurance reform than those in their prime working years. Before the reform, the near-elderly are the most likely to face high premiums and low coverage rates on the non-group market. The greater availability and lower price of alternatives to employer-provided health insurance is akin to an increase in wealth, and this wealth effect could increase employment exits, allow people to switch to a "bridge job,” or otherwise change employers.

Furthermore, the labor market for near-elderly workers could be impacted through the combination of job turnover rates and the early retirement of some workers. If employeremployee matches are improved through higher turnover, older workers may desire to work longer. Broader health insurance coverage could also improve the health of older workers (Rutledge 2016). Together, firms might also find hiring and retaining older workers more attractive than before the reform since the average older worker is healthier, leading to longer working lives through both the supply of and demand for older workers.

Early evidence suggested that job lock substantially hindered workers' mobility. The New York Times (1991) reported that three out of 10 Americans have at one point stayed in a job 
in order to maintain their health insurance benefits, which is consistent with the estimates of 1535 percent found in the economics literature (for example, Cooper and Monheit, 1993;

Buchmueller and Valleta, 1996; Gruber and Madrian, 1997; Adams, 2004.) Monheit and Cooper (1994) estimated that the welfare lost due to job lock is between $\$ 3.7$ and $\$ 4.8$ billion. Gruber and Madrian (2004), in a comprehensive review of the literature, concluded that while estimates of the extent of job lock vary, the vast majority of studies to that point found a quantitative and statistically significant negative effect on the labor market.

Furthermore, the evidence suggested that expanding the availability of group health insurance to employees that separate from a firm greatly increases the willingness of current employees to leave and reduces the degree of job lock. Gruber and Madrian find that the availability of an extra year of COBRA coverage increased mobility among prime working-age men by 10 percent (1994), increased the retirement hazard by 30 percent (1995) and the probability of being retired by 1 percent (1996) for men aged 55-64, and increases the incidence and duration of joblessness (1997). However, expanding COBRA and the MA health insurance reform are very different, and thus may have very different effects. First, the reform provides a lower-priced, easy-to-find health insurance alternative that is not associated with a job. This could lead to lower turnover relative to COBRA. However, the MA non-group reforms do not have time limits like COBRA coverage—-which may increase turnover relative to COBRA. Furthermore, the reform has an individual mandate while COBRA coverage is optional, so the reform impacts the entire population, not only those who place a high value on health insurance.

Some recent studies have also found results consistent with job lock, and the easing of job lock through expanded coverage. Hamersma and Kim (2009) and Farooq and Kugler (2016) find that Medicaid expansions—-which was one element of Massachusetts reform—have reduced job lock and allowed for workers to switch to higher-risk, higher-reward occupations and industries.

Most recent evidence, however, suggests that job lock does not substantially restrict workers' ability to change jobs. The adoption of the Health Insurance Portability and Accountability Act (HIPAA) in 1996 provides the most important test, considering that its purpose was to relieve the pressure of job lock. But the legislation appears to have had only a small effect on job mobility in general (Sanz-de-Galdeano 2006) and transitions into small firms in particular (Kapur 2003, 2004). Results from the ACA's mandate to provide dependent care 
benefits to young individuals on their parents' insurance plans up to age 26 (Bailey and Chorniy 2016) also suggest little evidence of an increase in job mobility. Preliminary results from the first year of full ACA implementation also indicate no effect on labor market outcomes such as labor force participation (Kaestner et al 2015) or early retirement (Levy, Buchmueller, and Nikpay 2015; Gustman, Steinmeier, and Tabatabai 2016).

While the Massachusetts reforms maintain an employer delivery system, the individual mandates and non-group insurance market reforms could still greatly reduce the inefficiencies of this system. Some studies have found changes consistent with workers being "locked" into their jobs before reform: for example, Niu (2014) finds that 8 percent more workers reported selfemployment in Massachusetts after the reform, and Heim and Lin (2016) find a 23 percent decrease in early retirement among women, but no effect for men. But most evidence suggests that the reform had no statistically detectable effect. Sanzenbacher (2014) finds no difference in unemployment rates. Dubay, Long, and Lawton (2012) also find no difference in overall employment rates between Massachusetts and control states, and no difference in employment by firm size. In the closest paper to ours, Sachs (2013), using self-reported job transitions from the Survey of Income and Program Participation (SIPP), finds little difference in job mobility.

\section{Estimation Methods}

The analysis examines whether prime-aged individuals are more likely to move between employers, in particular from large to small firms, after the implementation of the Massachusetts health insurance reform in 2007. It also examines whether workers, and in particular older individuals (age 55-65), are more likely to exit employment.

The analysis uses difference-in-difference methods, comparing the change in the rate of changing employers or exiting employment in Massachusetts before and after 2007 to the change in these variables over the same time period in control states. The control states consist of most of the other New England states (Maine, New Hampshire, Rhode Island, and Connecticut; Vermont is excluded because they also implemented health reform) and New York.

The outcomes of interest are indicators for 1) changing employers; 2) changing jobs from a large firm to a small firm, conditional on changing jobs between times $t-1$ and $t$; 3 ) changing jobs from a small firm to a large firm, conditional on changing jobs between times $t-1$ and $t$; and 4) moving from employment to non-employment. Job lock theory suggests that the reform 
should increase employer changes, transitions from large to small firms (conditional on changing jobs), and employment exits; and decrease transitions from small to large firms (conditional on changing jobs). ${ }^{2}$

The structure of the model for each outcome $Y$ is:

$$
Y_{i j t}=\beta_{0}+\gamma X_{i j, t-1}+\beta_{1} M A_{i j t}+\beta_{2} \text { Post }_{i t}+\beta_{12} M A_{i j t} \times \text { Post }_{i t}+\varepsilon_{i j t}
$$

in which $i$ indexes individuals, $j$ indexes states, and $t$ indexes time. $X_{i j, t-1}$ is a limited set of individual and state-level characteristics in year t-1: age (in 5-year categories), gender, race, participation in a defined contribution plan, earnings quartile, and the state unemployment rate in year $t . M A_{i j t}$ is a dummy variable equal to one if the worker lives and/or works in

Massachusetts. Post ${ }_{i t}$ is an indicator for whether the year of observation $t$ is from 2008 or later; because the reform was still in progress in 2007, we consider 2007 to be part of the pre-reform period. The key coefficient on the interaction of $M A_{i j t}$ and Post $_{i t}$, which signifies the effect of living and/or working in Massachusetts after health reform was implemented on labor market outcomes.

We also try to disentangle the effects of the employer and individual mandates, by exploiting the information on the worker's residence and the location of their primary employer. Individuals who live in Massachusetts but work in New Hampshire are only subject to the individual mandate; Massachusetts workers who live elsewhere are only subject to the employer mandate. Interaction terms are added to assess if there are differential effects for people who cross state borders when they commute to work.

$$
\begin{aligned}
Y_{i t}=\alpha_{0}+\delta & X_{i j, t-1}+\alpha_{1} \text { MAresident }_{i j t}+\alpha_{2} \text { MAemploye }_{i j t}+\alpha_{3} \text { Post }_{t} \\
& +\alpha_{13} \text { MAresident }_{i j t} \times \text { Post }_{i t}+\alpha_{23} \text { MAemploye }_{i j t} \times \text { Post }_{i t} \\
& +\alpha_{123} \text { MAresident }_{i j t} \times \text { MAemploye }_{i j t} \times \text { Post }_{i t}+v_{i j t}
\end{aligned}
$$

MAresident $_{i j t}$ is equal to one if the worker's state of residence is Massachusetts.

MAemploye $_{i j t}$ is equal to one if the employer is located in Massachusetts. For most workers, these indicator variables will both equal zero — indicating that they neither lived nor worked in

\footnotetext{
${ }^{2}$ Health reform may actually increase the unconditional transition rate from small to large firms if it increases employee mobility generally - that is, it allows more people to make transitions of all kinds, including transitions from large firm to another large firm, or a small firm to another small firm. But conditional on moving employers in any way, health reform should reduce the incentive to move to a large firm from a small firm. To make the results more clearly match this conceptual framework, we present results for the transition of moving from small to large firms, or large to small firms, conditional on making any employer change.
} 
Massachusetts_-or both equal to one_-indicating that they were Massachusetts residents working in Massachusetts. Identification of the separate effects of the individual and employer mandates derives from the workers who cross state borders for work, either to or from Massachusetts. The interaction coefficient $\alpha_{13}$ represents the effect of the individual mandate alone, while the interaction coefficient $\alpha_{23}$ isolates the effect of the employer mandate.

\section{Data}

This project uses administrative data from the Social Security Administration's Continuous Work History Sample (CWHS) merged with the Longitudinal Employee-Employer Data (LEED) File for the years 2000-2011. The CWHS is based on a one-percent sample of earnings and beneficiary records, which include a limited set of individual characteristics, including demographics. The LEED File includes the worker's state of residence and information on his primary employer, including that firm's Employer Identification Number (EIN) and location. ${ }^{3}$

Table 1 lays out the creation of the sample. The CWHS-LEED merged file includes about 3 million person-years for people who live and/or work in Massachusetts or its surrounding states (the rest of New England and New York). Vermont also implemented a health insurance expansion in 2007 (Thorpe 2007), so we drop anyone who lives or works in Vermont to make sure that the control group consists only of residents of states without reform. In addition, we drop workers who made the initial geographic cut only because their employers are based in the Northeast; we assume that if they live outside of New England (excluding Vermont) or New York, they do not actually work in those states. These two geographic cuts leave the sample with 2.1 million, among whom about 1.3 million (or 247,000 unique individuals) are between ages 30-64. The analyses include about 180,000 unique persons who

\footnotetext{
${ }^{3}$ The Social Security Administration constructs the CWHS from the Master Earnings File and the Master Beneficiary Record, sampling earnings and beneficiary records based on certain digits of the social security number (SSN) and following that random sample throughout their careers. SSA uses further information from the Employee-Employer (EE-ER) file, which includes one record for each employer-employee combination. In addition to earnings from each job, the data elements on the EE-ER file include the state and county of the employer's address of record from the Form SS-4 (Application for Identification Number), and the employee's state and county of residence from the W-2 form. The LEED is a longitudinal version of the EE-ER file, sorted by SSN, year, and EIN. For employees with more than one job in a given year, we selected the EIN of the employer from whom worker received the highest total compensation in any year to represent employer location and firm size.
} 
are not missing an EIN in either of two consecutive years and, for the regressions, are not missing individual characteristics.

Individuals are defined as working if they accumulate at least 4 quarters of coverage for Social Security (summing all jobs) in a given year. This restriction eliminates workers who did not have substantial earnings from any one employer, which should be related to working sufficient hours to qualify for health coverage. Employment exit is defined as working (and earning at least 4 quarters of coverage) in year $t-1$ but not in year $t$. The employer change outcome is also restricted to individuals who are working both periods; it is an indicator equal to one if the individual's EIN of their primary employer changed from one year to the next.

The other key variable needed to construct the outcome variables is firm size. The CWHS-LEED data do not include a direct measure of the number of employees, but the dataset is large enough to sample multiple employees of the same firm. Figure 1 presents a histogram of the number of workers associated with each EIN. We set the threshold for a large firm at 5 or more workers sampled in the CWHS-LEED File from the same EIN; because the data is a random one-percent sample, this corresponds to several hundred workers, which is fairly large for a "large firm." As a result, 61 percent of the sample works in a large firm by this definition; the Bureau of Labor Statistics reports that about 72 percent of individuals work for firms with 50 or more employees in 2015, so our large-firm sample represents a somewhat smaller share of the workforce than in the U.S. economy as a whole. Still, we use a more conservative (larger) threshold because a small number of employees happening to make it into the sample for any one firm could skew the picture of how many employees that firm actually has. As a robustness check, we also present results using two other definitions of large firm: 1) having more than one employee (77 percent of the sample); and 2) having more than two employees (69 percent). These samples better correspond to the traditional definition of large firms based on scaling up the 1-percent sample, and more closely match the magnitudes in the U.S. labor force, but likely some small firms will be mis-assigned when they have more than one or two workers sampled by chance. For both transitions from large to small firms, and from small to large firms, we limit the sample to individuals who are making any kind of employer change.

Administrative data are not without some limitations and complications. First, only limited demographic information is available. Little can be done to address this issue, and we believe that the gain in sample size and reporting accuracy far outweighs this weakness. Second, 
in order to identify employment changes, we rely on changes in one's employer's EIN over time. This would be ideal if the EINs were stable over time-however, firms are constantly reinventing themselves through the entry and exit of establishments, the entry and exit of firms, mergers and acquisitions, outsourcing, changes in ownership, changes in legal form of organization and changes in the products and services produced by the establishments and the firms. Administrative identifiers typically change along with these types of firm changes. If the merger/acquisition rate does not vary between states over time, then our identification strategy is still valid; however, that assumption is difficult to validate.

\section{Descriptive Statistics}

Table 2 summarizes the key variables in the analysis. Before reform, Massachusetts workers differed slightly from the other northeastern states. ${ }^{4}$ Massachusetts residents are less likely to be black or Hispanic, have slightly higher earnings, and are more likely to participate in a 401(k) plan, but otherwise are similar to workers in other states. Massachusetts also enjoyed a lower unemployment rate in the 2000-2006 period. After reform, most of these differences persist, except that Massachusetts’ unemployment rate was nearly equal to the rate in the other states.

The bottom rows of Table 2 present the means for the outcome variables for the sample regardless of age; Massachusetts workers were more likely to change employers overall, and make both large-to-small firm and small-to-large firm transitions than workers in the rest of the Northeast. Exit rates to non-employment are comparable by residence in both periods.

Table 3 presents the unadjusted difference-in-differences estimates by age, comparing the change in each outcome variable in Massachusetts from pre- to post-reform with the change over the same period in other northeastern states. These changes are presented separately for the prime-aged (35-54, Panel A) and older (55-64, Panel B) samples.

Before reform, the rate at which workers changed employers was just under 2 percentage points greater in Massachusetts than in the rest of the northeast for each age group. In the period after reform, the share of workers changing employers in any given year fell in all states and in

\footnotetext{
${ }^{4}$ In each table and figure, any individual living or working in Massachusetts is included in the MA category; individuals in the "Northeast" category neither live nor work in Massachusetts, but each individual lives in New York or the other New England states (excluding Vermont).
} 
both age groups. But this rate of changing employers fell more in Massachusetts: by 3.4 percentage points (compared to 2.6 percentage points in the rest of the northeast) for prime-age workers, and by 2.6 percentage points (versus 1.7 percentage points in the rest of the northeast) for older workers. The difference-in-differences, therefore, shows that Massachusetts' rate of decline was 0.8 percentage points greater for both prime-age and older workers. The job-lock literature would have suggested precisely the opposite, but it appears that Massachusetts workers were actually less likely to leave their employers after health reform.

Another prediction of the job-lock literature is that reform would allow for Massachusetts workers to move to smaller firms (including self-employment), and inspire fewer transitions from small firms to large firms by workers seeking employer-sponsored insurance coverage. However, the unadjusted difference-in-differences results are again inconsistent with theory. While the large-to-small transition rate fell only slightly in the rest of the Northeast, the decrease was larger in Massachusetts-by about 3 percentage points for younger workers and 5 percentage points for older workers. The small-to-large transition rate increased across the board, but by slightly more for Massachusetts workers of both ages.

The easing of job lock would have predicted a greater increase in employment exits among older individuals in Massachusetts. However, the unadjusted difference-in-difference results show that the decline in the rate of exit from employment was almost exactly equal in Massachusetts and the rest of the northeast.

Figure 2 shows the path of job transitions around the Massachusetts reform for primeaged workers who either live or work in Massachusetts, and compares these probabilities to individuals who neither work nor live in the state. The top panel indicates that the rate of transitioning across employers has been falling fairly steadily for workers in both Massachusetts and in the other New England states. Massachusetts workers were more likely to change jobs in every year, but the difference between Massachusetts and other New England states has grown smaller-even excluding 2001-2002 when the transition rate was much larger in Massachusetts than it was in any other year, the gap has shrunk from 2 percentage points in 2004-2006 to 1.2 percentage points in 2008-2011. Regardless of the exact size, this convergence is the opposite of what we would expect if reform had reduced job lock; the hypothesized effect would have been for Massachusetts' job transition rate to increase, or at least for the trend to fall slower than it did in other states. 
The middle panel shows the rate of transitioning from large firms to small firms, among workers who were working in large firms in year $t-1$ but also changed employers. As in the top panel, the transition probability has fallen over time. And as with the top panel, this figure shows a greater decline for Massachusetts residents and workers, which is the opposite of what is expected if job lock had previously prevented workers from moving to small firms that did not offer insurance.

The bottom panel shows the opposite transition—from small firms to large firms, among job-changers. As expected, this transition rate is lower in Massachusetts in 2010 and 2011 than before reform, while other states' small-to-large transition rates were essentially unchanged. But the small-to-large transition rate in Massachusetts in 2008 and 2009 was higher than in preceding years, so the effect of the reform is hard to assess.

Figure 3 shows the patterns for these transitions for the older group, age 55-64. The job mobility graphs in Figure 3 tell the same story for older workers that Figure 2 told for primeaged workers: the reform did not appear to ease mobility, and if anything Massachusetts lost most of its mobility advantage over other states.

Figure 4 charts the change over time in exit rates from employment for the two age groups. The reform was expected to increase the likelihood that Massachusetts workers would leave their jobs, given that they had an alternative source of coverage. While the probability of employment exit did rise in Massachusetts in 2009 for prime-age workers, it did so in other states as well, likely because of the Great Recession. Thereafter, the exit rate settled at a level similar to pre-reform. For older workers, the reform seems to have had the opposite of its expected effect for employment exit: Massachusetts workers were increasingly less likely to leave employment, with a sharper decline than workers in other states (lower panel).

Importantly for our estimation strategy, none of the above figures indicates that Massachusetts workers saw a different trend in labor market outcomes than in the control states before the reform. Appendix Table A1 shows statistically insignificant estimates on the interaction between the Massachusetts indicator and a linear time trend in the 2000-2006 period.

\section{Estimation Results}

The results from the unconditional difference-in-differences suggest that the Massachusetts reform did not have a major impact on job lock; in fact, most evidence indicates 
that mobility and employment exits fell by more in Massachusetts than in states that did not increase insurance availability outside of employment. But the summary statistics in Table 2 suggested that Massachusetts residents, and its workforce, differed somewhat from other states both before and after reform. These differences motivate the basic regression analysis, the results of which are reported in Table 4.

The top panel of Table 4 presents estimates for individuals ages 30-54 who worked in year $t$-1. Estimates where the dependent variable is an indicator for changing employers are presented in the first row. Massachusetts had a higher rate of employer changes throughout 2000-2010, even controlling for other characteristics. As suggested in the unconditional difference-in-differences, the rate of change in employers was lower in all states after reform, and especially lower in Massachusetts. The negative and statistically significant interaction of Massachusetts and post-2007 indicates that the decline in the rate of changing employers was greater in Massachusetts than in the control states. ${ }^{5}$

The second row of the top panel of Table 4 examines transitions from large firms to small firms, among workers who make any job change. For the full sample period, Massachusetts workers are more likely to make this transition compared to residents of other northeastern states. But the gap with other states closed after reform - the interaction coefficient is negative and statistically significant, and of almost the same magnitude as the Massachusetts indicator without an interaction. This result runs counter to the theoretical prediction, but is consistent with the unconditional difference-in-differences.

The difference-in-differences estimate of transitions from small to large firms also presents little evidence that jobs were "unlocked” (third row). The difference between Massachusetts and other states is small and statistically insignificant, so workers do not appear to have reduced their probability of switching to a large firm after reform, in opposition to theory.

Job lock suggests that workers in Massachusetts would be more likely to exit employment after reform. But the estimates in the fourth row of the top panel of Table 4 indicate that exit rates did not change in any statistically significant way after reform.

The bottom panel of Table 4 reports analogous results for the sample of workers ages 5564. After reform, older Massachusetts workers were less likely to change employers, and less

\footnotetext{
${ }^{5}$ All results are similar in regressions where each state has its own dummy variable and interaction with the postreform indicator to allow for state-specific breaks in trend at the same time as the health reform.
} 
likely to move from large to small firms (conditional on changing employers), than older workers in the rest of the northeast. Older Massachusetts workers also had no difference in the probability of moving to a large firm or exiting employment. The estimates in Table 4, therefore, indicate that the Massachusetts reform did not "unlock" jobs that would have been helped by increased access to health insurance outside of employment.

One prediction of job-lock theory that is not explicitly tested in Table 4 is that workers with health insurance at time $t-1$ will be more likely to change employers. Because the data lacks information on health insurance coverage either before or after an employment transition, we proxy for having employer-sponsored health insurance by controlling for working at a large firm at $t-1$, since nearly all workers at large firms have health coverage (Long, Rae, and Claxton 2016). The dependent variable in Table 5 is once again an indicator for changing employers, but the independent variables now include an indicator for working in a large firm interacted with the Massachusetts indicator, the post-reform dummy, and their interaction. As in the earlier regressions, the sample includes residents and workers from Massachusetts and surrounding states.

Contrary to theory, but consistent with the results in Table 4, the triple-difference estimates in Table 5 show statistically significant decreases in changing employers among individuals who are living and/or working in Massachusetts and who worked in large firms in the prior year. Massachusetts residents/workers who worked for a small firm in year $t-1$ had no statistically significant difference in their likelihood of changing employers after the reform, as indicated by the interaction of Massachusetts residence/employment and the post-reform indicator. The results are similar in sign, magnitude, and significance by age and gender.

\section{Massachusetts Residents vs. Massachusetts Employees}

One of the benefits to the administrative data used in this project is the ability to identify workers who cross into or out of Massachusetts for work (subject to some measurement errore.g., with companies that are headquartered in Massachusetts but where the employee is located elsewhere). Table 6 indicates that 2.1 percent of the sample, or nearly 24,000 people, work for a Massachusetts employer but live elsewhere; these workers benefited from the employer mandate, but were not subject to the individual mandate. In addition, 5.2 percent of the sample, or more than 60,000 people, live in Massachusetts but work elsewhere; these workers were subject to the 
individual mandate, but their employer was not obligated to offer them insurance by the employer mandate.

The results in Table 7 take advantage of the 7.3 percent of the sample that crosses the Massachusetts border to separately identify the impacts of the individual and employer mandates. The first row of each set of results presents the un-interacted coefficients, while the second row shows the interaction effects.

The results for both Massachusetts residents who work elsewhere (second column) and out-of-state residents who work in Massachusetts (third column) contradict the prediction, but agree with the unconditional results and the earlier regression estimates. Massachusetts residents who work elsewhere are about 3 percentage points less likely to change employers, a statistically significant estimate, and are less likely (albeit statistically insignificantly) to move from a large to a small firm. Residents of other states who work in Massachusetts are in the third column: they are also statistically significantly less likely both to change employers and to move from large to small firms. Interestingly, one estimate each for these two groups does actually fit with a theoretical prediction: MA residents working elsewhere are less likely to move to a large firm after reform, and MA workers who reside elsewhere are more likely to exit employment.

The fourth column presents the triple-difference results for Massachusetts residents who also work in Massachusetts. Note that these figures are the estimates for the differential between Massachusetts residents who work within the state and those workers who cross state boundaries. Interestingly, the within-Massachusetts workers are statistically significantly more likely than the border-crossers to change employers or move from large to small firms, but the magnitude of the differential essentially cancels out the effect of either living or working in Massachusetts (but not both).

\section{Results by Gender}

Tables 8 and 9 repeat the difference-in-differences analysis (with only one Massachusetts indicator, for living and/or working in the state) separately by gender, to determine whether the extent to which jobs were “unlocked” by Massachusetts' health reform differs for men and women. One possibility is that men are more affected by health insurance in their decision to change jobs if they are still the breadwinners in the majority of households; this possibility may be especially true for older households, so the analysis is once again estimated separately for 
prime-aged and older households. On the other hand, women tend to be more risk averse (see Outreville (2014) for a review), and could be more cautious about maintaining health coverage and thus respond more to freer access to insurance outside of employment.

Table 8 presents the results at ages 30-54 (as in the top panel of Table 4). The results are largely the same for women (top panel) and men (bottom panel). In each case, the probability of changing employers actually fell in Massachusetts after the reform, as did the transition rate from large to small firms (though only statistically significantly for men). The estimates for small-tolarge firm transitions and employment exits are small and statistically insignificant for both genders.

Table 9 repeats the analysis for older men and women. The patterns are similar, except that the decrease in the large-to-small transitions rates is statistically significant for both groups, not just women. Also, employment exits decrease in a statistically significant way for men, with no significant change in either direction for women. These results all run counter to the predicted direction of the effect of reform on labor market outcomes.

\section{Robustness Checks}

The above results indicate little evidence that workers are freer to change employers, move to a small firm, avoid working for a large firm, or exit employment after the implementation of Massachusetts' health insurance reform. Tables 10-12 test the robustness of these results.

First, Table 10 presents results excluding observations where either year $t-1$ or year $t$ are from calendar year 2007. The reform began in 2007, but enrollment in Commonwealth Connector and Medicaid was slow to ramp up during 2007 (Cohn 2013); as a result, the reform may not have influenced labor market decisions until after the structure of the new market was better established and understood. But the results are similar to Table 4: even with the postreform period limited to 2008 or later, transitions across employers and into small firms both decreased statistically significant for prime-age workers. For older workers, employer transitions were little changed (and insignificant), but transitions from large to small firms fell in a statistically significant way, as did employment exits, while transitions into large firms significantly increased. 
Second, Table 11 presents results where Massachusetts is compared only to the other New England states (excluding Vermont), but not also New York. Though Massachusetts abuts New York, that border is far from each state's respective population hubs; crossing that state border is rarer than, say, movement across the New Hampshire or Rhode Island borders, since both are close enough to enable regular commuting to Boston. Given the closer populationweighted geography, the control group in Table 11 should be more similar to the Massachusetts population. But the results are similar to previous estimates: a statistically significant decrease in employer-changing in Massachusetts relative to this smaller set of states, and no evidence that transitions from large to small firms, or out of employment, increased. The one exception: older workers are somewhat more likely to move from small to large firms.

Third, the definition of "small firm"-fewer than five employees in the CWHS 1-percent sample in that year-may include too many large firms; after all, four sampled workers should correspond to 400 employees in the population if the sampling is entirely random across employers. This expansive definition may understate transitions between small and large firms. Table 12 presents separate results using two alternative definitions of small firms. The top panel classifies a firm as small if it only has one employee in the sample (about 23 percent of firms). The estimates for large-to-small transitions using that definition are statistically insignificant and small for both age groups, and small-to-large transitions are surprisingly positive and statistically significant for prime-age workers, but negative and statistically significant for transitions from small to large firms, in keeping with theory. The bottom panel categorizes firms as small if it has at most two employees in the sample (about 31 percent of firms). There is no evidence of any change in transition rates for prime-age workers under this definition, and statistically significant evidence of a decline in employer changes for older workers, but again the small-to-large transition rates falls as expected for workers age 55 and older. Other than some evidence that older workers are less likely to seek out jobs at large firms when alternative means of acquiring health insurance are available — evidence that does not concur with the rest of the estimates in this study — the results are robust to these alternative definitions.

\section{Conclusion}

One of the goals of both Massachusetts' health reform in the mid-2000s and the ACA that followed a similar model was to ease job lock, the idea that workers avoid changing 
employers—especially to small firms or self-employment—because they fear losing access to their health insurance. Similarly, workers who would rather retire, take care of a loved one, or otherwise opt not to work instead remain in a job to maintain health benefits, or are forced to find a new job to gain coverage.

The predicted response to these reforms was that employer mobility should have increased, especially to small firms, and employment exits should have increased. Because the ACA was rolled out nationally and all at once, the Massachusetts reform is better designed for evaluating whether these predictions have come true. This project uses administrative data on employment relationships to determine whether mobility across employers and out of employment increased.

The results provide very little evidence that Massachusetts' reform eased job lock. Some workers in select groups decreased the rate at which they moved to large firms, as predicted. But most of the predictions about labor market mobility did not come to pass: employer transition rates decreased more in Massachusetts than in neighboring states, as did transitions from large to small firms and out of employment altogether. Further, there is little evidence that either the employer mandate or any of the individual-side reforms — the individual mandate, Medicaid expansion, or the creation of the Commonwealth Connector-had separate effects on the labor market.

On the whole, the results suggest 1) that job lock was not tying workers to unproductive jobs in Massachusetts to the extent that earlier research had suggested; 2) that the Massachusetts reform may not have eased workers' concerns about access to health insurance enough to make them consider moving jobs or leaving employment; or 3) the premiums, even when subsidized, for plans purchased on the Connector did not make individual coverage attractive enough relative to employer-sponsored insurance to ease job lock. This result runs contrary to wellestablished labor economic theory. The null result, however, is consistent with recent literature, including the initial results from the ACA (e.g., Kaestner et al 2015). The recent spate of null results suggests that COBRA and HIPAA may have reduced job lock to the point where it would be hard to detect in policies that further increased access outside of the worker's current employer. In the case of the ACA in particular, null results are likely related to the uncertainty surrounding the law's political fate and concerns that the plans available on the exchange would not match employer-sponsored insurance in price and quality. 
This study uses administrative data with large sample sizes, which should allow for the effect of health reform on labor market mobility to be more easily detectable, yet the results provide little evidence that the reform eased job lock. Still, this dataset is short on individual characteristics - most importantly workers' initial health insurance status. The Massachusetts reform was also implemented immediately before the Great Recession, so post-reform outcomes are likely affected by the downturn — in particular, workers may have felt apprehensive about changing employers, especially to a small firm, if it increased their exposure to job loss, even if health insurance reform made such a move more feasible (though the effect of the recession on Massachusetts was similar to neighboring states). Therefore, further work is needed to establish whether more freely available health insurance, and at what price, will reduce labor market inefficiencies, to the extent that they exist. 


\section{References}

Adams, Scott J. 2004. “Employer-Provided Health Insurance and Job Change.” Contemporary Economic Policy 22(3): 357-369.

Bailey, James and Anna Chorniy. 2016. "Employer-Provided Health Insurance and Job Mobility: Did the Affordable Care Act Reduce Job Lock?” Contemporary Economic Policy 34(1): 173-83.

Buchmueller, Thomas C. and Robert G. Valletta. 1996. “The Effects of Employer-Provided Health Insurance on Worker Mobility.” Industrial and Labor Relations Review 49(3): 439-455.

Centers for Medicare \& Medicaid Services. 2009. NHE Fact Sheet. Baltimore, MD. Available at: https://www.cms.gov/NationalHealthExpendData/25_NHE_Fact_Sheet.asp\#TopOfPage.

Cohn, Jonathan. 2013. “A Chart that Will Help Dispel Your Obamacare Hysteria.” The New Republic, October 23, available online at https://newrepublic.com/article/115309/obamacare-enrollment-massachusetts-statisticssuggest-it-will-be-slow.

Cooper, Philip F. and Alan C. Monheit. 1993. "Does Employment-Related Health Insurance Inhibit Job Mobility?” Inquiry 30(4): 400-416.

Courtemanche, Charles J. and Daniela Zapata. 2014. "Does Universal Coverage Improve Health? The Massachusetts Experience.” Journal of Policy Analysis and Management 33(1): 36-69.

Dubay, Lisa, Sharon K. Long, and Emily Lawton. 2012. "Will Health Reform Lead to Job Loss? Evidence from Massachusetts Says No.” Timely Analysis of Immediate Health Policy Issues Brief. Washington, DC: The Urban Institute.

Farooq, Amaar and Adriana Kugler. 2016. "Beyond Job Lock: Impacts of Public Health Insurance on Occupational and Industrial Mobility.” Working Paper 22118. Cambridge, MA: National Bureau of Economic Research.

Gruber, Jonathan and Brigitte C. Madrian. 1994. "Health Insurance and Job Mobility: The Effects of Public Policy on Job Lock.” Industrial and Labor Relations Review 48(1): 86102.

Gruber, Jonathan and Brigitte C. Madrian. 1995. "Health Insurance Availability and the Retirement Decision.” American Economic Review 85(4): 938-948. 
Gruber, Jonathan and Brigitte C. Madrian. 1996. "Health Insurance and Early Retirement: Evidence from the Availability of Continuation Coverage.” In Advances in the Economics of Aging, edited by David A Wise, 115-143. Chicago, IL: University of Chicago Press.

Gruber, Jonathan and Brigitte C. Madrian. 1997. "Employment Separation and Health Insurance Coverage.” Journal of Public Economics 66(3): 349-382.

Gruber, Jonathan and Brigitte C. Madrian. 2004. “Health Insurance, Labor Supply, and Job Mobility: A Critical Review of the Literature.” In Health Policy and the Uninsured, edited by Catherine McLaughlin, 97-178. Washington, DC: Urban Institute Press.

Gustman, Alan L., Thomas L. Steinmeier, and Nahid Tabatabai. 2016. "The Affordable Care Act as Retiree Health Insurance: Implications for Retirement and Social Security Claiming.” Working Paper 22815. Cambridge, MA: National Bureau of Economic Research.

Hamersma, Sarah and Matthew Kim. 2009. “The Effect of Parental Medicaid Expansions on Job Mobility.” Journal of Health Economics 28(2009): 761-770.

Health Connector. 2011. Health Reform Facts and Figures. Available at: https://www.mahealthconnector.org/portal/binary/com.epicentric.contentmanagement.ser vlet.ContentDeliveryServlet/Health\%2520Care\%2520Reform/Facts\%2520and\%2520Fig ures/Facts\%2520and\%2520Figures.pdf.

Heim, Bradley T. and Leekai Lin. 2016. "Does Health Reform Lead to an Increase in Early Retirement? Evidence from Massachusetts.” Industrial and Labor Relations Review, forthcoming.

Jost, Timothy. 2014. "Repeal, and Replace, the Employer Mandate.” Health Affairs blog post, June 4, 2014, available at: http://healthaffairs.org/blog/2014/06/04/repeal-and-replacethe-employer-mandate/, last accessed June 21, 2016.

Kaestner, Robert, Bowen Garrett, Anuj Gangopadhyaya, and Caitlyn Fleming. 2015. "Effects of ACA Medicaid Expansions on Health Insurance Coverage and Labor Supply.” Working Paper 21836. Cambridge, MA: National Bureau of Economic Research.

Kapur, Kanika. 2003. “Labor Market Implications of State Small Group Health Insurance Reform.” Public Finance Review 31(6): 571-600.

Kapur, Kanika. 2004. "The Impact of the Health Insurance Market on Small Firm Employment.” Journal of Risk and Insurance 71(1): 63-90.

Levy, Helen, Thomas Buchmueller and Sayeh Nikpay. 2015. “The Effect of Health Reform on Retirement”. Working Paper 2015-329. Ann Arbor, MI: Michigan Retirement Research Center. 
Long, Michelle, Matthew Rae, and Gary Claxton. 2016. “A Comparison of the Availability and Cost of Coverage for Workers in Small Firms and Large Firms: Update from the 2015 Employer Health Benefits Survey.” Issue Brief. Menlo Park, CA: Henry J. Kaiser Family Foundation.

Long, Sharon K. 2008. "On the Road to Universal Coverage: Impacts of Reform in Massachusetts at One Year.” Health Affairs 27 (4): 270-84.

Long, Sharon K. and Heather Dahlen. 2014. "Expanding Coverage to Low-Income Childless Adults in Massachusetts: Implications for National Health Reform.” Health Services Research 49(6): 2129-2146.

Long, Sharon K., Karen Stockley, and Heather Dahlen. 2012. "Massachusetts Health Reforms: Uninsurance Remains Low, Self-Reported Health Status Improves as State Prepares to Tackle Costs.” Health Affairs 31(2): 444-451.

Miller, Sarah. 2012. “The Effect of the Massachusetts Reform on Health Care Utilization.” Inquiry 49(4): 317-326.

Miller, Sarah. 2012. “The Impact of the Massachusetts Health Care Reform on Health Care Use Among Children.” American Economic Review: Papers \& Proceedings 102(3): 502-507.

Monheit, Alan C. and Philip F. Cooper. 1994. "Health Insurance and Job Mobility: Theory and Evidence.” Industrial and Labor Relations Review 48(1): 68-85.

New York Times. 1991. "Health Benefits Found to Deter Switches in Jobs.” (September 26). New York, NY.

Niu, Xiaotong. 2014. "Health Insurance and Self-Employment: Evidence from Massachusetts." Industrial and Labor Relations Review 67(4): 1235-1273.

Outreville, J. Francois. 2014. "Risk Aversion, Risk Behavior, and Demand for Insurance: A Survey.” Journal of Insurance Issues 37(2): 158-186.

Rutledge, Matthew S. 2016. “The Interconnected Relationships of Health Insurance, Health, and Labor Market Outcomes.” Working Paper 2016-2. Chestnut Hill, MA: Center for Retirement Research at Boston College.

Sachs, Rebecca Marqusee. 2013. "Job-Lock and Health Insurance Premiums: Evidence from the Massachusetts Health Care Reform.” Working Paper. Stanford, CA: Stanford University Department of Economics.

Sanzenbacher, Geoffrey T. 2014. "What We Know About Health Reform in Massachusetts.” Issue in Brief 14-9. Chestnut Hill, MA: Center for Retirement Research at Boston College. 
Sanz-de-Galdeano, Anna. 2006. “Job-Lock and Public Policy: Clinton’s Second Mandate.” Industrial and Labor Relations Review 59(3): 430-437.

Sommers, Benjamin D., Sharon K. Long, and Katherine Baicker. 2014. "Changes in Mortality after Massachusetts Health Care Reform: A Quasi-Experimental Study.” Annals of Internal Medicine 160(9): 585-593.

Thorpe, Kenneth E. 2007. "Vermont’s Catamount Health: A Roadmap for Health Care Reform?” Health Affairs 26(6): 703-705.

U.S. Census Bureau. 2010. Income, Poverty, and Health Insurance Coverage in the United States: 2009. Washington, DC: US Department of Commerce, Current Population Reports P60-238. Available at: http://www.census.gov/prod/2010pubs/p60-238.pdf.

Van der Wees, Philip J., Alan M. Zaslavsky, and John Z. Ayanian. 2013. "Improvements in Health Status after Massachusetts Health Care Reform.” Milbank Quarterly 91(4): 663689. 
Table 1. Sample Selection

\begin{tabular}{lcc}
\hline & Person-years & Unique persons \\
\hline Living and/or working in New England or New York & $2,997,227$ & \\
Living in New England (excluding VT) or New York & $2,141,328$ & \\
Between ages 30-64 & $1,338,228$ & 246,973 \\
Not missing EIN in consecutive years (for graphical analysis) & $1,169,235$ & 180,176 \\
Not missing individual characteristics (for regression analysis) & $1,156,326$ & 179,615 \\
\hline
\end{tabular}

Source: Continuous Work History Sample 2000-2011. 
Table 2. Summary Statistics Before and After Reform, MA vs. Northeast

\begin{tabular}{|c|c|c|c|c|c|c|}
\hline & \multicolumn{2}{|c|}{ All years } & \multicolumn{2}{|c|}{ Pre-reform } & \multicolumn{2}{|c|}{ Post-reform } \\
\hline & MA & Northeast & MA & Northeast & MA & Northeast \\
\hline Number of individuals & 44,424 & 143,915 & 37,440 & 122,609 & 30,926 & 102,813 \\
\hline Number of person-years & 264,651 & 891,675 & 167,704 & 566,875 & 96,947 & 324,800 \\
\hline Number of businesses (EIN) & 30,466 & 101,856 & 24,097 & 79,825 & 16,770 & 56,094 \\
\hline Small firms & 0.46 & 0.47 & 0.47 & 0.47 & 0.45 & 0.46 \\
\hline Large firms & 0.54 & 0.53 & 0.53 & 0.53 & 0.55 & 0.54 \\
\hline Firm size & 105 & 283 & 102 & 282 & 112 & 286 \\
\hline Median Medicare taxable wages & 36,936 & 34,931 & 34,429 & 32,822 & 41,964 & 39,058 \\
\hline Age (continuous) & 45.2 & 45.2 & 44.7 & 44.8 & 46.0 & 46.0 \\
\hline White & 0.70 & 0.61 & 0.71 & 0.62 & 0.68 & 0.60 \\
\hline Black & 0.05 & 0.10 & 0.05 & 0.10 & 0.05 & 0.10 \\
\hline Asian & 0.03 & 0.04 & 0.03 & 0.04 & 0.04 & 0.04 \\
\hline Hispanic & 0.03 & 0.06 & 0.03 & 0.06 & 0.04 & 0.07 \\
\hline Other & 0.01 & 0.01 & 0.01 & 0.02 & 0.01 & 0.01 \\
\hline Male & 0.51 & 0.50 & 0.51 & 0.50 & 0.50 & 0.50 \\
\hline Participating in a $401(\mathrm{k})$ & 0.45 & 0.39 & 0.45 & 0.38 & 0.47 & 0.41 \\
\hline State unemployment rate & 5.3 & 5.6 & 4.6 & 5.0 & 6.6 & 6.7 \\
\hline $\begin{array}{l}\text { Employer change | Employed in } \\
t-1\end{array}$ & 0.14 & 0.12 & 0.15 & 0.13 & 0.12 & 0.11 \\
\hline Large to small | Changed employers & 0.39 & 0.37 & 0.40 & 0.37 & 0.37 & 0.37 \\
\hline Small to large | Changed employers & 0.34 & 0.32 & 0.34 & 0.32 & 0.35 & 0.33 \\
\hline Exit | Employed in $t-1$ & 0.03 & 0.03 & 0.03 & 0.03 & 0.03 & 0.03 \\
\hline
\end{tabular}

Notes: "Northeast" excludes Massachusetts and Vermont.

Source: Continuous Work History Sample-Longitudinal Employee-Employer Data merged file, 2000-2011. 
Table 3. Unadjusted Difference-in-Differences in Labor Market Outcomes, MA vs. Northeast

\begin{tabular}{lcccccc}
\hline & \multicolumn{2}{c}{ Pre-reform } & & \multicolumn{2}{c}{ Post-reform } & Difference in \\
\cline { 2 - 3 } & MA & Northeast & & MA & Northeast & differences \\
\hline Ages 30-54 & & & & & & \\
Employer change (+) & 0.161 & 0.143 & & 0.127 & 0.117 & -0.008 \\
Large to small (+) & 0.403 & 0.376 & & 0.373 & 0.371 & -0.026 \\
Small to large (-) & 0.336 & 0.320 & & 0.351 & 0.332 & 0.003 \\
Exit (+) & 0.029 & 0.032 & & 0.028 & 0.031 & 0.000 \\
& & & & & & \\
Ages 55-64 & & & & & & \\
Employer change (+) & 0.107 & 0.089 & & 0.081 & 0.072 & -0.008 \\
Large to small (+) & 0.411 & 0.366 & & 0.354 & 0.362 & -0.054 \\
Small to large $(-)$ & 0.331 & 0.302 & & 0.358 & 0.321 & 0.008 \\
Exit (+) & 0.036 & 0.040 & & 0.031 & 0.037 & -0.003 \\
\hline
\end{tabular}

Notes: "Northeast" excludes Massachusetts and Vermont. Large-to-small and small-to-large transition rates are among workers making any employer change. Hypothesized direction in parentheses after each outcome. Source: Continuous Work History Sample-Longitudinal Employee-Employer Data merged file, 2000-2011. 
Table 4. Linear Probability Model Estimates for Labor Market Outcomes

\begin{tabular}{lcccr}
\hline & \multicolumn{3}{c}{ Independent variables } & \multirow{2}{*}{ N and $\mathrm{R}^{2}$} \\
\cline { 2 - 4 } Dependent variable & Post-reform & MA & MA $\times$ Post & \\
\hline Ages 30-54 & $-0.013^{* * *}$ & $0.020^{* * *}$ & $-0.006^{* * *}$ & 849,447 \\
Changing employers & $(0.002)$ & $(0.003)$ & $(0.002)$ & 0.052 \\
Large to small | Changing & 0.006 & $0.022^{*}$ & $-0.020^{* *}$ & 51,677 \\
& $(0.011)$ & $(0.011)$ & $(0.010)$ & 0.022 \\
Small to large | Changing & $0.019^{* * *}$ & $0.0135^{* * *}$ & 0.0036 & 64,634 \\
& $(0.007)$ & $(0.0036)$ & $(0.0077)$ & 0.018 \\
Exiting employment & $0.0026^{* * *}$ & 0.00031 & 0.00048 & 876,550 \\
Ages 55-64 & $(0.0009)$ & $(0.00069)$ & $(0.00106)$ & 0.068 \\
Changing employers & & & & 190,814 \\
& $-0.010^{* * *}$ & $0.017^{* * *}$ & $-0.007^{* * *}$ & 0.022 \\
Large to small | Changing & $(0.001)$ & $(0.003)$ & $(0.002)$ & 7,433 \\
& -0.016 & $0.044^{* *}$ & $-0.052^{* * *}$ & 0.020 \\
Small to large | Changing & $(0.016)$ & $(0.021)$ & $(0.010)$ & 8,748 \\
& 0.014 & $0.029^{* *}$ & 0.010 & 0.012 \\
Exiting employment & $(0.017)$ & $(0.012)$ & $(0.017)$ & 198,313 \\
& 0.0004 & $-0.0038^{* * *}$ & $-0.0016^{* *}$ & 0.059 \\
\hline
\end{tabular}

Notes: Each row is a separate regression; MA and MA $\times$ Post coefficients are relative to residents of New York and other states in New England. Regressions also include age, gender, race and Hispanic ethnicity, defined contribution pension participation, state unemployment rate, and Medicare taxable wage quartile. Significance is indicated to the 1-percent level $(* * *)$, 5-percent level $(* *)$, and 10-percent level $(*)$.

Source: Continuous Work History Sample-Longitudinal Employee-Employer Data merged file, 2000-2011. 
Table 5. Employer Change Regressions Including Interactions with Firm Size

\begin{tabular}{|c|c|c|}
\hline & Age 30-54 & Age 55-64 \\
\hline Large firm & $\begin{array}{l}-0.024^{* * *} \\
(0.003)\end{array}$ & $\begin{array}{l}-0.014 * * * \\
(0.002)\end{array}$ \\
\hline Post-reform & $\begin{array}{l}-0.015^{* * *} \\
(0.002)\end{array}$ & $\begin{array}{l}-0.011^{* * *} \\
(0.002)\end{array}$ \\
\hline$\times$ large firm & $\begin{array}{l}0.004^{* * * *} \\
(0.001)\end{array}$ & $\begin{array}{r}0.002 \\
(0.002)\end{array}$ \\
\hline MA residence/employment & $\begin{array}{l}0.018^{* * *} \\
(0.004)\end{array}$ & $\begin{array}{l}0.012^{* * *} \\
(0.003)\end{array}$ \\
\hline$\times$ large firm & $\begin{array}{r}0.005 \\
(0.003)\end{array}$ & $\begin{array}{l}0.011^{* * *} \\
(0.002)\end{array}$ \\
\hline$\times$ Post-reform & $\begin{array}{r}-0.002 \\
(0.002)\end{array}$ & $\begin{array}{l}-0.001 \\
(0.002)\end{array}$ \\
\hline$\times$ large firm $\times$ Post & $\begin{array}{l}-0.007^{* * *} \\
(0.001)\end{array}$ & $\begin{array}{l}-0.012^{* * *} \\
(0.003)\end{array}$ \\
\hline Sample size & 849,235 & 181,300 \\
\hline $\mathrm{R}^{2}$ & 0.053 & 0.023 \\
\hline
\end{tabular}

Note: Other the interactions displayed above, regressions include the same controls as the other regressions. Significance is indicated to the 1-percent level (***) and 5-percent level (**).

Source: Continuous Work History Sample-Longitudinal Employee-Employer Data merged file, 2000-2011.

Table 6. Cross-Tabulation of MA Residence and Employment

\begin{tabular}{cccc}
\hline & & \multicolumn{2}{c}{ Employer location } \\
\cline { 3 - 4 } & & Other Northeast & Massachusetts \\
\hline \multirow{3}{*}{ State of } & Other & 891,675 & 23,664 \\
residence & Northeast & $77.1 \%$ & $2.1 \%$ \\
& MA & 60,593 & 180,394 \\
& & $5.2 \%$ & $15.6 \%$ \\
\hline
\end{tabular}

Source: Continuous Work History Sample-Longitudinal Employee-Employer Data merged file, 2000-2011. 
Table 7. Separate Linear Probability Estimates for MA Residence and Employment

\begin{tabular}{|c|c|c|c|c|c|c|c|c|c|}
\hline & \multicolumn{2}{|c|}{ Post-reform } & \multicolumn{2}{|c|}{ MA residence } & \multicolumn{2}{|c|}{ MA employment } & \multicolumn{2}{|c|}{$\begin{array}{c}\text { MA residence } \times \text { MA } \\
\text { employment }\end{array}$} & \multirow[t]{2}{*}{$\mathrm{N}$ and $\mathrm{R}^{2}$} \\
\hline \multicolumn{9}{|l|}{ Ages 30-54 } & \\
\hline Changing employers & -0.013 & $(0.002)^{* * *}$ & 0.067 & $(0.002)^{* * *}$ & 0.032 & $(0.005)^{* * *}$ & -0.096 & $(0.005)^{* * *}$ & 849,447 \\
\hline Interaction with Post & & & -0.031 & $(0.001)^{* * *}$ & -0.020 & $(0.004)^{* * *}$ & 0.054 & $(0.004) * * *$ & 0.053 \\
\hline Large to small | Changing & 0.006 & $(0.011)$ & 0.029 & $(0.012)^{* *}$ & 0.051 & $(0.014)^{* * *}$ & -0.072 & $(0.014) * * *$ & 51,677 \\
\hline Interaction with Post & & & -0.016 & $(0.011)$ & -0.038 & $(0.017)^{* *}$ & 0.037 & $(0.017)^{* *}$ & 0.023 \\
\hline Small to large | Changing & 0.020 & $(0.007) * * *$ & 0.078 & $(0.003)^{* * *}$ & -0.009 & $(0.010)$ & -0.069 & $(0.009)^{* * *}$ & 64,634 \\
\hline Interaction with Post & & & -0.045 & $(0.006)^{* * *}$ & 0.049 & $(0.038)$ & 0.007 & $(0.038)$ & 0.019 \\
\hline Exiting employment & 0.003 & $(0.001)^{* * *}$ & 0.004 & $(0.001)^{* * *}$ & -0.004 & $(0.002)^{* *}$ & -0.001 & $(0.002)$ & 876,550 \\
\hline Interaction with Post & & & -0.001 & $(0.001)$ & 0.006 & $(0.003)^{* *}$ & -0.005 & $(0.003)^{*}$ & 0.076 \\
\hline \multicolumn{10}{|l|}{ Ages $55-64$} \\
\hline Changing employers & -0.010 & $(0.001)^{* * *}$ & 0.056 & $(0.002)^{* * *}$ & 0.041 & $(0.010)^{* * *}$ & -0.094 & $(0.010) * * *$ & 190,814 \\
\hline Interaction with Post & & & -0.017 & $(0.001)^{* * *}$ & -0.018 & $(0.015)$ & 0.031 & $(0.015)^{* *}$ & 0.023 \\
\hline Large to small | Changing & -0.016 & $(0.016)$ & 0.023 & $(0.020)$ & 0.037 & $(0.051)$ & 0.002 & $(0.050)$ & 7,433 \\
\hline Interaction with Post & & & -0.036 & $(0.013)^{* * *}$ & -0.046 & $(0.048)$ & 0.018 & $(0.051)$ & 0.020 \\
\hline Small to large | Changing & 0.015 & $(0.017)$ & 0.043 & $(0.012)^{* * *}$ & -0.003 & $(0.037)$ & -0.011 & $(0.037)$ & 8,748 \\
\hline Interaction with Post & & & 0.005 & $(0.019)$ & 0.058 & $(0.015)^{* * *}$ & -0.059 & $(0.014) * * *$ & 0.012 \\
\hline Exiting employment & 0.000 & $(0.001)$ & 0.005 & $(0.002)^{* * *}$ & 0.002 & $(0.008)$ & -0.014 & $(0.008)^{*}$ & 198,313 \\
\hline Interaction with Post & & & -0.007 & $(0.001)^{* * *}$ & -0.006 & $(0.005)$ & 0.014 & $(0.005) * * *$ & 0.059 \\
\hline
\end{tabular}

Note: Each row is a separate regression. Regressions include both MA indicators plus the same controls as the other regressions. Significance is indicated to the 1percent level (***), 5-percent level $(* *)$, and 10-percent level $(*)$.

Source: Continuous Work History Sample-Longitudinal Employee-Employer Data merged file, 2000-2011. 
Table 8. Separate Linear Probability Estimates for MA Residence and Employment at Ages 3054, by Gender

\begin{tabular}{lcccr}
\hline & \multicolumn{3}{c}{ Independent variables } & \multirow{2}{*}{ N and $\mathrm{R}^{2}$} \\
\cline { 2 - 4 } Dependent variable & Post-reform & $\mathrm{MA}$ & $\mathrm{MA} \times$ Post & \\
Women & & & & \\
Changing employers & $-0.011^{* * *}$ & $0.021^{* * *}$ & $-0.008^{* * *}$ & 415,295 \\
& $(0.002)$ & $(0.003)$ & $(0.002)$ & 0.044 \\
Large to small | Changing & 0.009 & 0.011 & -0.003 & 26,193 \\
& $(0.008)$ & $(0.010)$ & $(0.008)$ & 0.019 \\
Small to large | Changing & 0.015 & 0.007 & 0.007 & 27,857 \\
& $(0.010)$ & $(0.006)$ & $(0.010)$ & 0.010 \\
Exiting employment & $0.002^{* * *}$ & $0.001^{* *}$ & 0.000 & 430,015 \\
& $(0.001)$ & $(0.000)$ & $(0.001)$ & 0.066 \\
Men & & & & \\
Changing employers & $-0.015^{* * *}$ & $0.021^{* * *}$ & $-0.004^{* *}$ & 434,152 \\
& $(0.001)$ & $(0.003)$ & $(0.002)$ & 0.063 \\
Large to small | Changing & 0.003 & $0.033^{* *}$ & $-0.037 * *$ & 25,484 \\
& $(0.016)$ & $(0.013)$ & $(0.018)$ & 0.024 \\
Small to large | Changing & $0.022^{* * *}$ & $0.018^{* * *}$ & 0.002 & 36,777 \\
& $(0.005)$ & $(0.005)$ & $(0.006)$ & 0.012 \\
Exiting employment & $0.003^{* * *}$ & 0.000 & 0.001 & 446,535 \\
& $(0.001)$ & $(0.001)$ & $(0.001)$ & 0.071 \\
\hline
\end{tabular}

Note: Each row is a separate regression. Regressions include the same controls as the other regressions. Significance is indicated to the 1-percent level $(* * *)$, 5-percent level $(* *)$, and 10-percent level $(*)$.

Source: Continuous Work History Sample-Longitudinal Employee-Employer Data merged file, 2000-2011. 
Table 9. Separate Linear Probability Estimates for MA Residence and Employment at Ages 5564, by Gender

\begin{tabular}{lcccr}
\hline & \multicolumn{3}{c}{ Independent variables } & \multirow{2}{*}{ N and $\mathrm{R}^{2}$} \\
\cline { 2 - 4 } Dependent variable & Post-reform & $\mathrm{MA}$ & $\mathrm{MA} \times$ Post & \\
Women & & & & \\
Changing employers & $-0.008^{* * *}$ & $0.016^{* * *}$ & $-0.004^{* *}$ & 96,044 \\
& $(0.002)$ & $(0.002)$ & $(0.002)$ & 0.018 \\
Large to small | Changing & $-0.044^{* *}$ & 0.021 & $-0.043^{* * *}$ & 3,580 \\
& $(0.022)$ & $(0.026)$ & $(0.014)$ & 0.015 \\
Small to large | Changing & -0.003 & $0.038^{* * *}$ & 0.003 & 3,840 \\
& $(0.021)$ & $(0.011)$ & $(0.027)$ & 0.019 \\
Exiting employment & 0.001 & $-0.005^{* * *}$ & 0.001 & 100,064 \\
& $(0.001)$ & $(0.001)$ & $(0.001)$ & 0.064 \\
Men & & & & \\
Changing employers & $-0.012^{* * *}$ & $0.019^{* * *}$ & $-0.010^{* *}$ & 94,770 \\
& $(0.001)$ & $(0.004)$ & $(0.004)$ & 0.026 \\
Large to small | Changing & 0.002 & 0.014 & $-0.021^{* *}$ & 96,931 \\
& $(0.008)$ & $(0.013)$ & $(0.009)$ & 0.015 \\
Small to large | Changing & 0.029 & 0.024 & 0.012 & 4,908 \\
& $(0.019)$ & $(0.015)$ & $(0.018)$ & 0.008 \\
Exiting employment & 0.000 & $-0.003^{*}$ & $-0.004^{* *}$ & 98,249 \\
& $(0.001)$ & $(0.002)$ & $(0.002)$ & 0.053 \\
\hline
\end{tabular}

Note: Each row is a separate regression. Regressions include both MA indicators plus the same controls as the other regressions. Significance is indicated to the 1-percent level $(* * *)$, 5-percent level $\left({ }^{* *}\right)$, and 10-percent level $(*)$. Source: Continuous Work History Sample-Longitudinal Employee-Employer Data merged file, 2000-2011. 
Table 10. Linear Probability Model Estimates for Labor Market Outcomes, Dropping 2007 Observations

\begin{tabular}{lcccr}
\hline & \multicolumn{3}{c}{ Independent variables } & N and $\mathrm{R}^{2}$ \\
\cline { 2 - 4 } Dependent variable & \multicolumn{2}{c}{ MA } & MA * Post & \\
\cline { 2 - 4 } Ages 30-54 & $-0.012^{* * *}$ & $0.020^{* * *}$ & $-0.005^{* * *}$ & 695,495 \\
Changing employers & $(0.003)$ & $(0.003)$ & $(0.002)$ & 0.053 \\
Large to small | Changing & 0.000 & $0.024^{*}$ & $-0.024^{* *}$ & 42,694 \\
& $(0.011)$ & $(0.014)$ & $(0.010)$ & 0.024 \\
Small to large | Changing & $0.025^{* * *}$ & $0.0122^{* * *}$ & 0.0041 & 53,445 \\
& $(0.007)$ & $(0.0040)$ & $(0.0091)$ & 0.018 \\
Exiting employment & -0.0002 & 0.00081 & 0.00081 & 717,935 \\
& $(0.0006)$ & $(0.00063)$ & $(0.00110)$ & 0.069 \\
Ages 55-64 & & & & \\
Changing employers & $-0.010^{* * *}$ & $0.017^{* * *}$ & -0.004 & 153,399 \\
Large to small | Changing & $(0.003)$ & $(0.003)$ & $(0.003)$ & 0.022 \\
& -0.025 & 0.043 & $-0.061^{* * *}$ & 6,095 \\
Small to large | Changing & $(0.018)$ & $(0.026)$ & $(0.022)$ & 0.020 \\
& 0.021 & 0.013 & $0.035^{* * *}$ & 7,096 \\
Exiting employment & $(0.018)$ & $(0.011)$ & $(0.015)$ & 0.012 \\
& $-0.0032^{* *}$ & $-0.0031^{* * *}$ & $-0.0021^{* * *}$ & 159,547 \\
& $(0.0015)$ & $(0.0009)$ & $(0.0007)$ & 0.061 \\
\hline
\end{tabular}

Note: Each row is a separate regression. Regressions include the same controls as the other regressions. Significance is indicated to the 1-percent level $(* * *)$, 5-percent level $(* *)$, and 10 -percent level $(*)$.

Source: Continuous Work History Sample-Longitudinal Employee-Employer Data merged file, 2000-2011. 
Table 11. Linear Probability Model Estimates for Labor Market Outcomes, Dropping New York Residents

\begin{tabular}{|c|c|c|c|c|}
\hline \multirow[b]{2}{*}{ Dependent variable } & \multicolumn{3}{|c|}{ Independent variables } & \multirow{2}{*}{$\mathrm{N}$ and $\mathrm{R}^{2}$} \\
\hline & Post-reform & MA & MA $\times$ Post & \\
\hline \multicolumn{5}{|l|}{ Ages 30-54 } \\
\hline Changing employers & $\begin{array}{l}-0.009 * * * \\
(0.003)\end{array}$ & $\begin{array}{l}0.019 \text { *** } \\
(0.007)\end{array}$ & $\begin{array}{l}-0.008^{* *} \\
(0.003)\end{array}$ & $\begin{array}{r}376,468 \\
0.053\end{array}$ \\
\hline Large to small | Changing & $\begin{array}{l}-0.040 * * \\
(0.017)\end{array}$ & $\begin{array}{r}-0.015 \\
(0.012)\end{array}$ & $\begin{array}{r}0.013 \\
(0.020)\end{array}$ & $\begin{array}{r}23,370 \\
0.022\end{array}$ \\
\hline Small to large | Changing & $\begin{array}{r}0.004 \\
(0.015)\end{array}$ & $\begin{array}{r}0.0101 \\
(0.0066)\end{array}$ & $\begin{array}{r}0.0138 \\
(0.0130)\end{array}$ & $\begin{array}{r}30,464 \\
0.013\end{array}$ \\
\hline Exiting employment & $\begin{array}{l}0.0052^{* * *} \\
(0.0014)\end{array}$ & $\begin{array}{r}0.00157 \\
(0.00112)\end{array}$ & $\begin{array}{r}-0.00201 \\
(0.00148)\end{array}$ & $\begin{array}{r}387,988 \\
0.071\end{array}$ \\
\hline Ages 55-64 & & & & \\
\hline Changing employers & $\begin{array}{l}-0.009^{* * *} \\
(0.004)\end{array}$ & $\begin{array}{l}0.014^{* * *} \\
(0.004)\end{array}$ & $\begin{array}{l}-0.007^{* *} \\
(0.003)\end{array}$ & $\begin{array}{r}85,951 \\
0.025\end{array}$ \\
\hline Large to small | Changing & $\begin{array}{r}-0.006 \\
(0.056)\end{array}$ & $\begin{array}{r}0.000 \\
(0.013)\end{array}$ & $\begin{array}{r}-0.050 \\
(0.042)\end{array}$ & $\begin{array}{l}3,437 \\
0.019\end{array}$ \\
\hline Small to large | Changing & $\begin{array}{l}0.061^{* * *} \\
(0.011)\end{array}$ & $\begin{array}{l}0.053^{* * * *} \\
(0.009)\end{array}$ & $\begin{array}{l}-0.032 * * * \\
(0.007)\end{array}$ & $\begin{array}{l}4,395 \\
0.014\end{array}$ \\
\hline Exiting employment & $\begin{array}{c}0.0033^{*} \\
(0.0017)\end{array}$ & $\begin{array}{r}-0.0007 \\
(0.0013)\end{array}$ & $\begin{array}{r}-0.0026 \\
(0.0016)\end{array}$ & $\begin{array}{r}89,047 \\
0.062 \\
\end{array}$ \\
\hline
\end{tabular}

Note: Each row is a separate regression. Regressions include the same controls as the other regressions. Significance is indicated to the 1-percent level $(* * *)$, 5-percent level $(* *)$, and 10 -percent level $(*)$.

Source: Continuous Work History Sample-Longitudinal Employee-Employer Data merged file, 2000-2011. 
Table 12. Linear Probability Model Estimates for Labor Market Outcomes Using Alternate Definitions of Small and Large Firms

\begin{tabular}{|c|c|c|c|c|}
\hline \multirow[b]{2}{*}{ Dependent variable } & \multicolumn{3}{|c|}{ Independent variables } & \multirow{2}{*}{$\mathrm{N}$ and $\mathrm{R}^{2}$} \\
\hline & Post-reform & MA & MA $\times$ Post & \\
\hline \multicolumn{5}{|c|}{ Small firm $=1$ sampled employee } \\
\hline \multicolumn{5}{|c|}{ Ages 30-54 } \\
\hline \multirow[t]{2}{*}{ Large to small | Changing } & 0.000 & -0.006 & 0.001 & 78,714 \\
\hline & $(0.005)$ & $(0.007)$ & $(0.008)$ & 0.017 \\
\hline \multirow[t]{2}{*}{ Small to large | Changing } & $0.016^{*}$ & $0.0142 * * *$ & $0.0246 * * *$ & 37,597 \\
\hline & $(0.009)$ & $(0.0051)$ & $(0.0055)$ & 0.015 \\
\hline \multicolumn{5}{|l|}{ Ages 55-64 } \\
\hline \multirow[t]{2}{*}{ Large to small | Changing } & -0.009 & -0.004 & -0.010 & 11,158 \\
\hline & $(0.006)$ & $(0.013)$ & $(0.012)$ & 0.012 \\
\hline \multirow[t]{2}{*}{ Small to large | Changing } & 0.006 & $0.060 * * *$ & $-0.042 * * *$ & 5,023 \\
\hline & $(0.010)$ & $(0.018)$ & $(0.015)$ & 0.012 \\
\hline \multicolumn{5}{|c|}{ Small firm $=1-2$ sampled employees } \\
\hline \multicolumn{5}{|c|}{ Ages 30-54 } \\
\hline \multirow[t]{2}{*}{ Large to small | Changing } & 0.006 & 0.000 & 0.001 & 64,517 \\
\hline & $(0.009)$ & $(0.010)$ & $(0.009)$ & 0.020 \\
\hline \multirow[t]{2}{*}{ Small to large | Changing } & $0.030 * * *$ & $0.0174 * * *$ & -0.0048 & 51,794 \\
\hline & $(0.007)$ & $(0.0047)$ & $(0.0089)$ & 0.018 \\
\hline \multicolumn{5}{|l|}{ Ages 55-64 } \\
\hline \multirow[t]{2}{*}{ Large to small | Changing } & $-0.015 * *$ & $0.030 * *$ & $-0.051 * * *$ & 9,324 \\
\hline & $(0.007)$ & $(0.015)$ & $(0.010)$ & 0.015 \\
\hline \multirow[t]{2}{*}{ Small to large | Changing } & 0.001 & $0.036 * * *$ & $-0.023 *$ & 6,857 \\
\hline & $(0.010)$ & $(0.012)$ & $(0.012)$ & 0.011 \\
\hline
\end{tabular}

Note: Each row is a separate regression. Regressions include the same controls as the other regressions.

Significance is indicated to the 1-percent level (***), 5-percent level (**), and 10-percent level (*).

Source: Continuous Work History Sample-Longitudinal Employee-Employer Data merged file, 2000-2011. 
Figure 1. Histogram of Firms by Number of Employees, 2000-2011

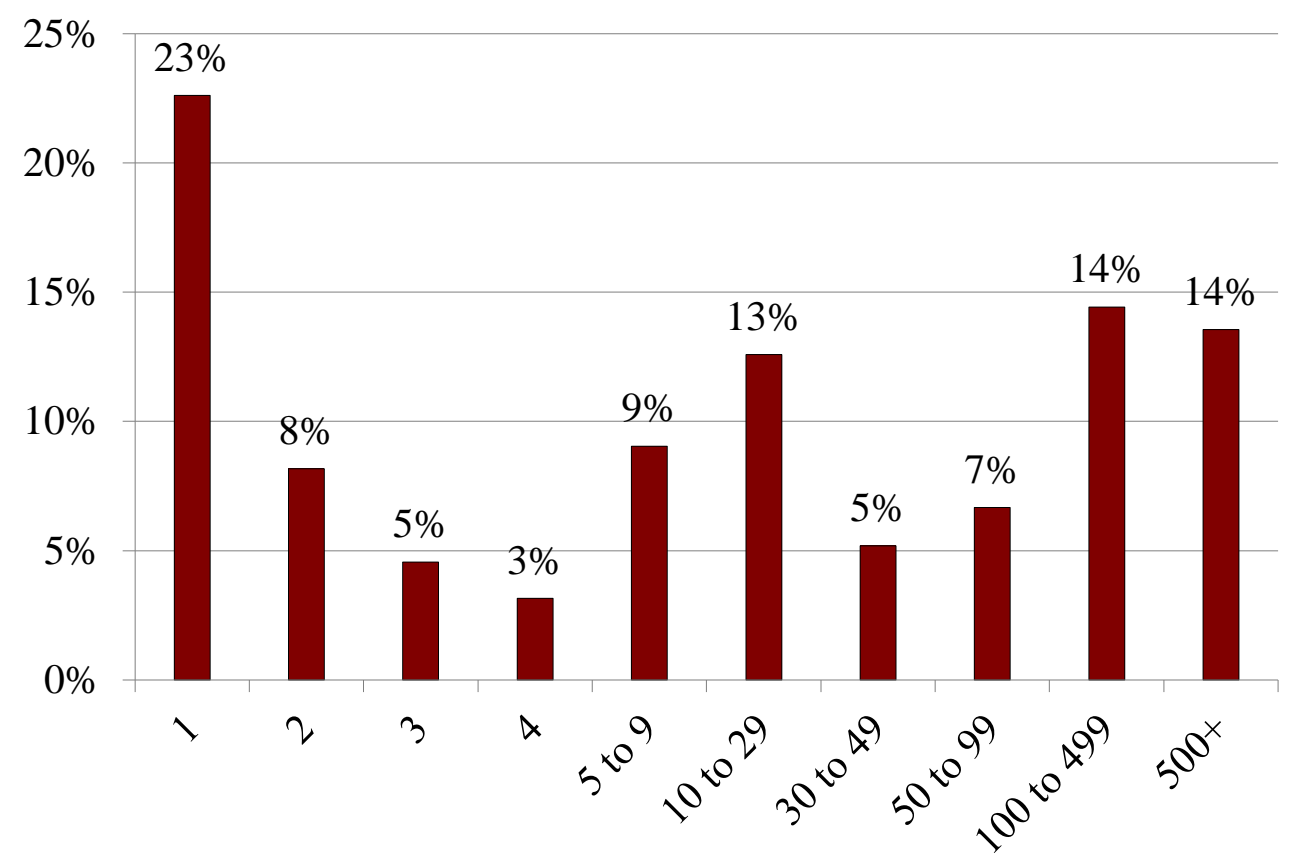

Source: Continuous Work History Sample-Longitudinal Employee-Employer Data merged file, 2000-2011. 
Figure 2. Employer-to-Employer Transitions Over Time at Ages 30-54, MA vs. Northeast

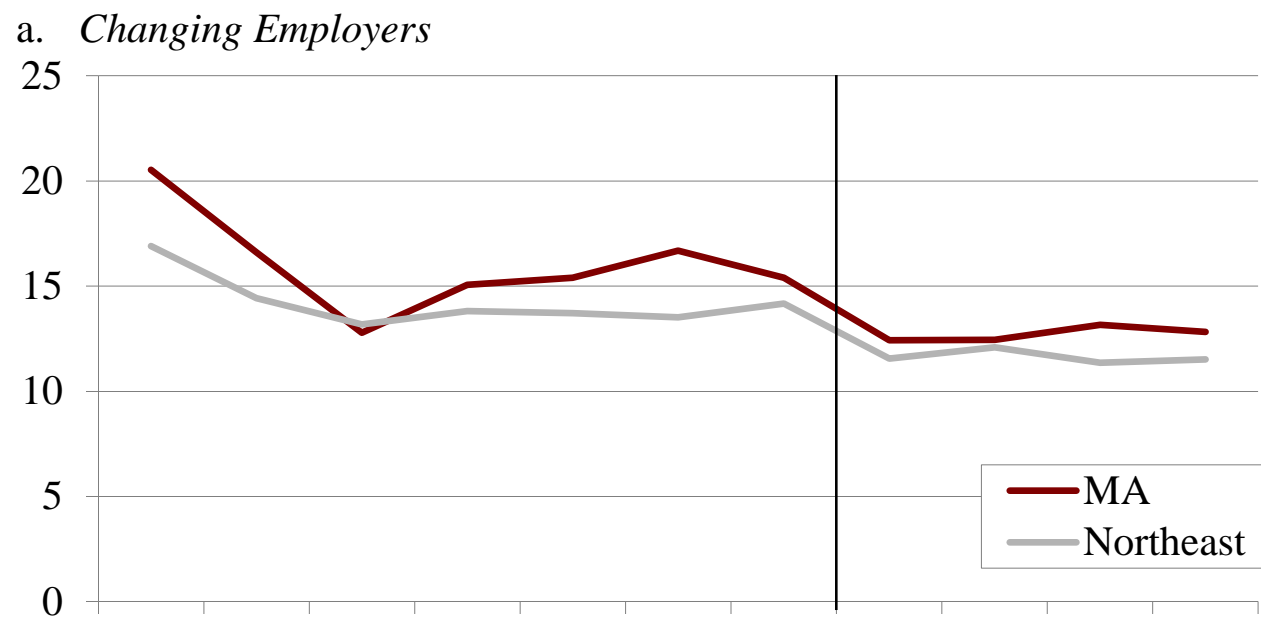

20012002200320042005200620072008200920102011

b. Large Employer to Small Employer

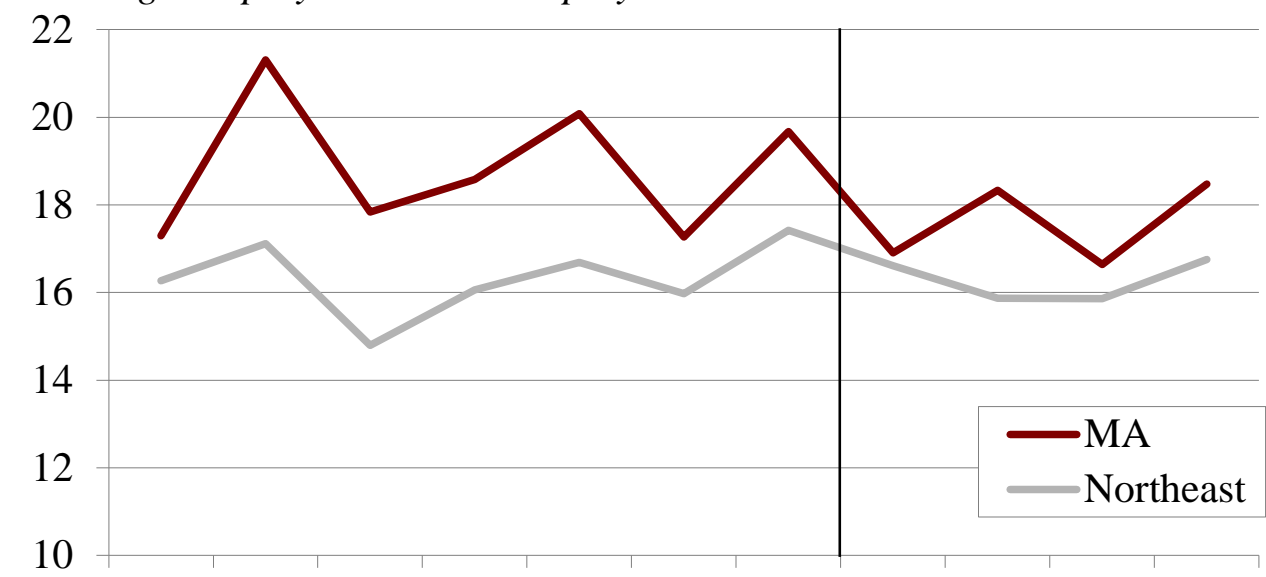

20012002200320042005200620072008200920102011

c. Small Employer to Large Employer

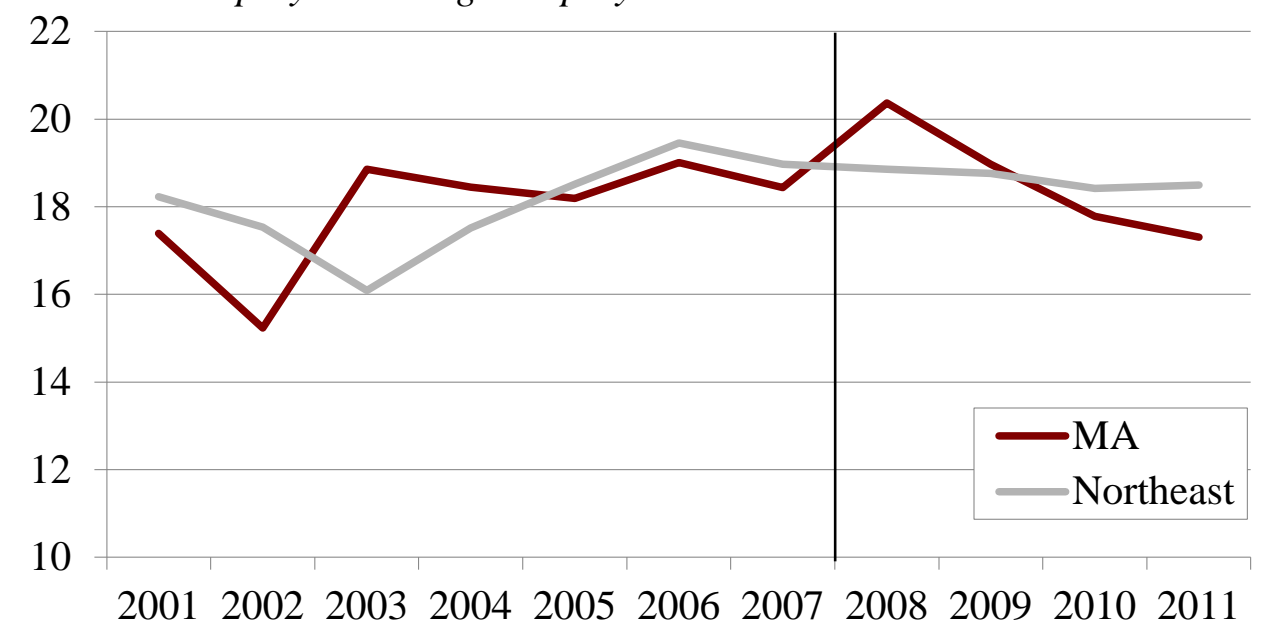

Source: Continuous Work History Sample-Longitudinal Employee-Employer Data merged file, 2000-2011. 
Figure 3. Employer-to-Employer Transitions Over Time at Ages 55-64, MA vs. Northeast

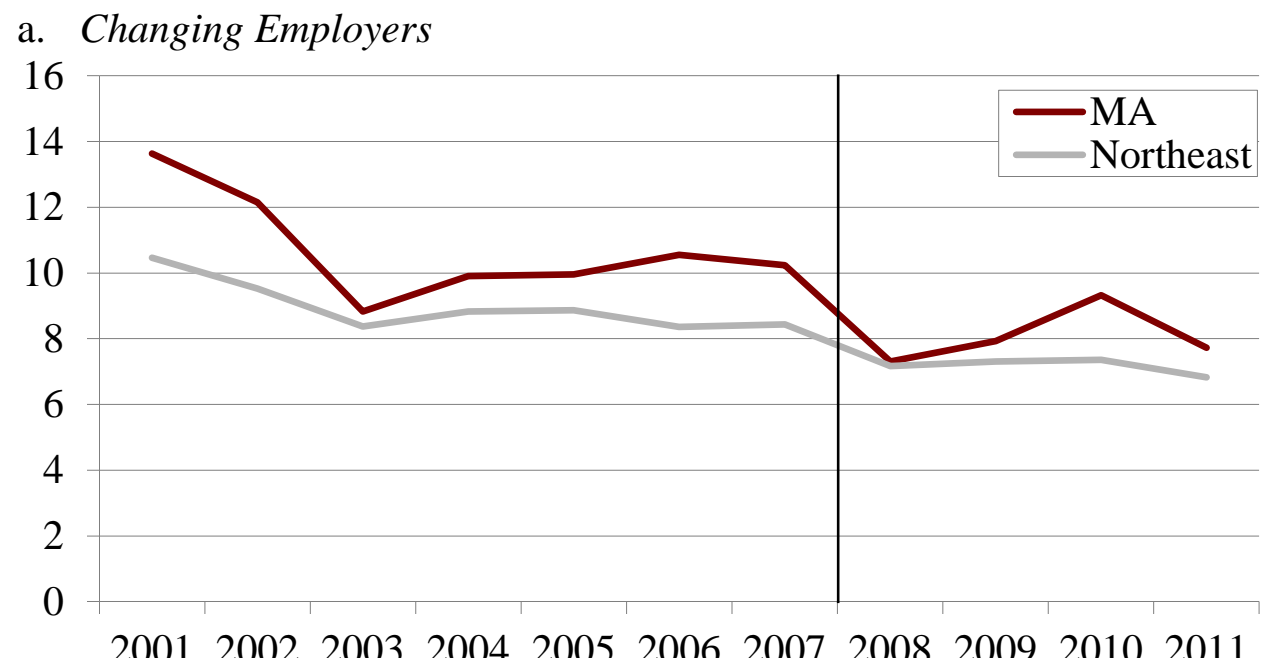

b. Large Employer to Small Employer

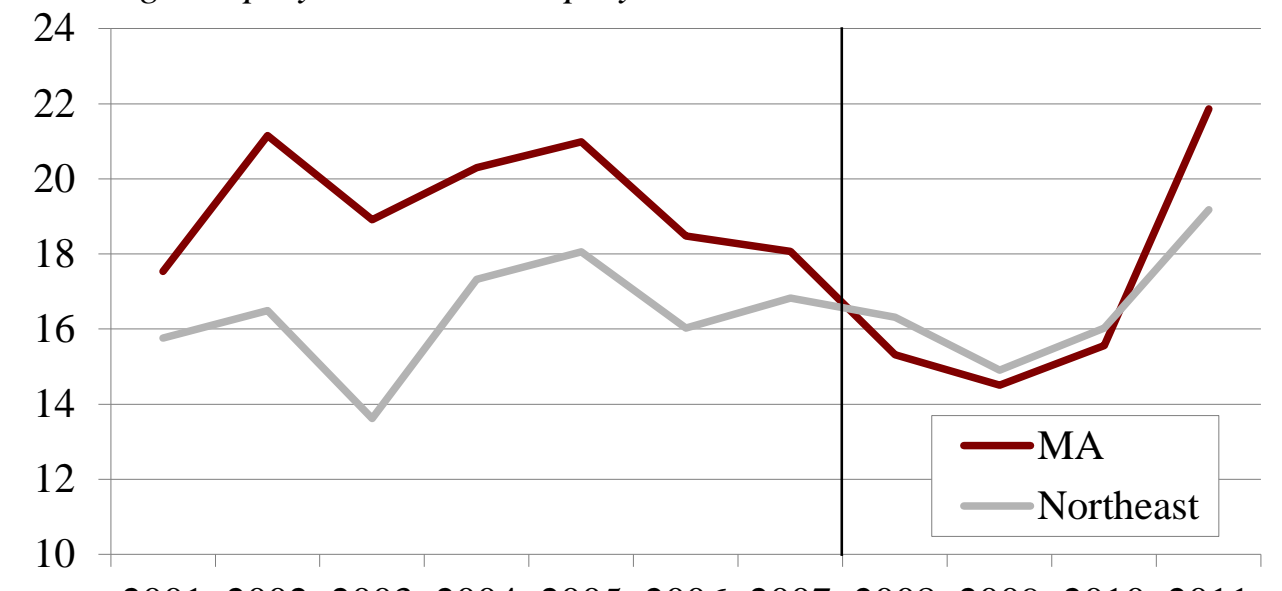

20012002200320042005200620072008200920102011

c. Small Employer to Large Employer

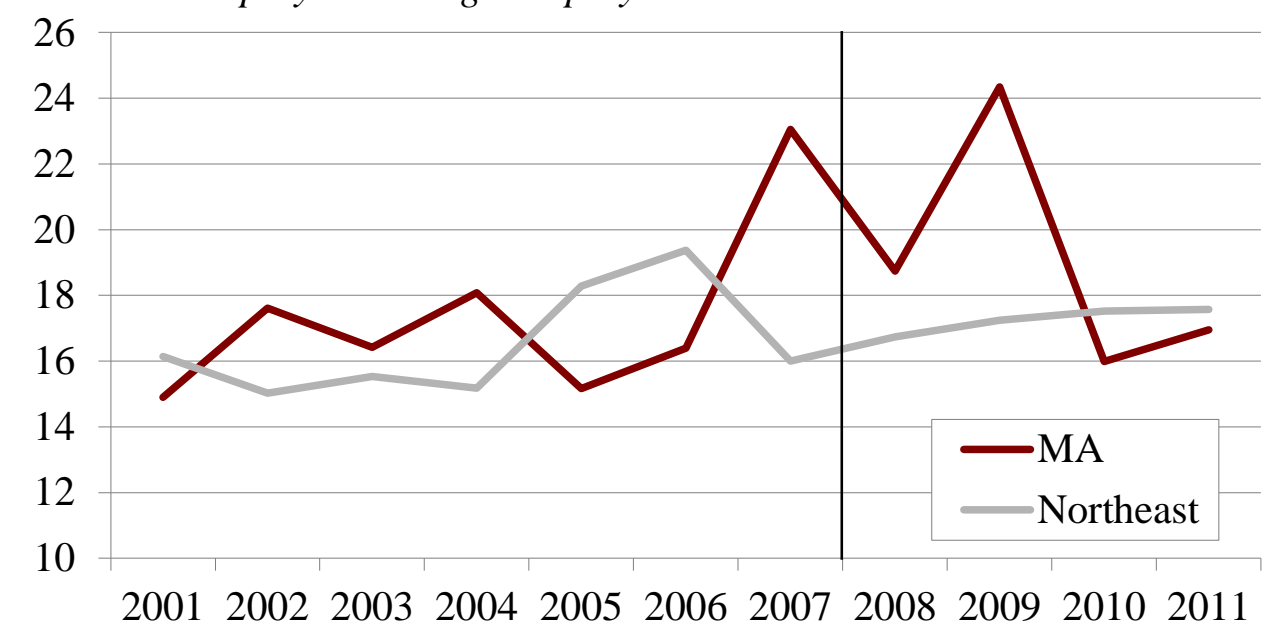

Source: Continuous Work History Sample-Longitudinal Employee-Employer Data merged file, 2000-2011. 
Figure 4. Exit from Employment Over Time by Age, MA vs. Northeast

a. Ages 30-54

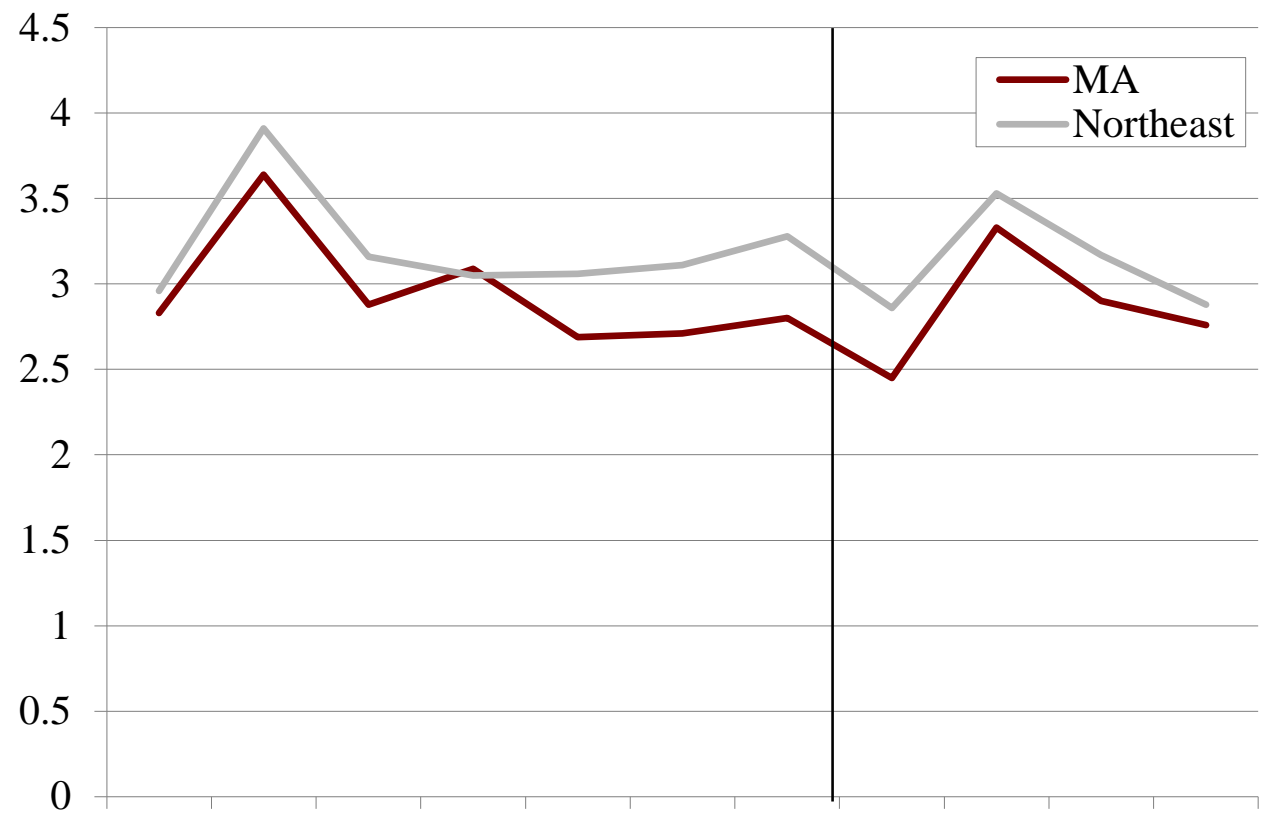

20012002200320042005200620072008200920102011

b. Ages 55-64

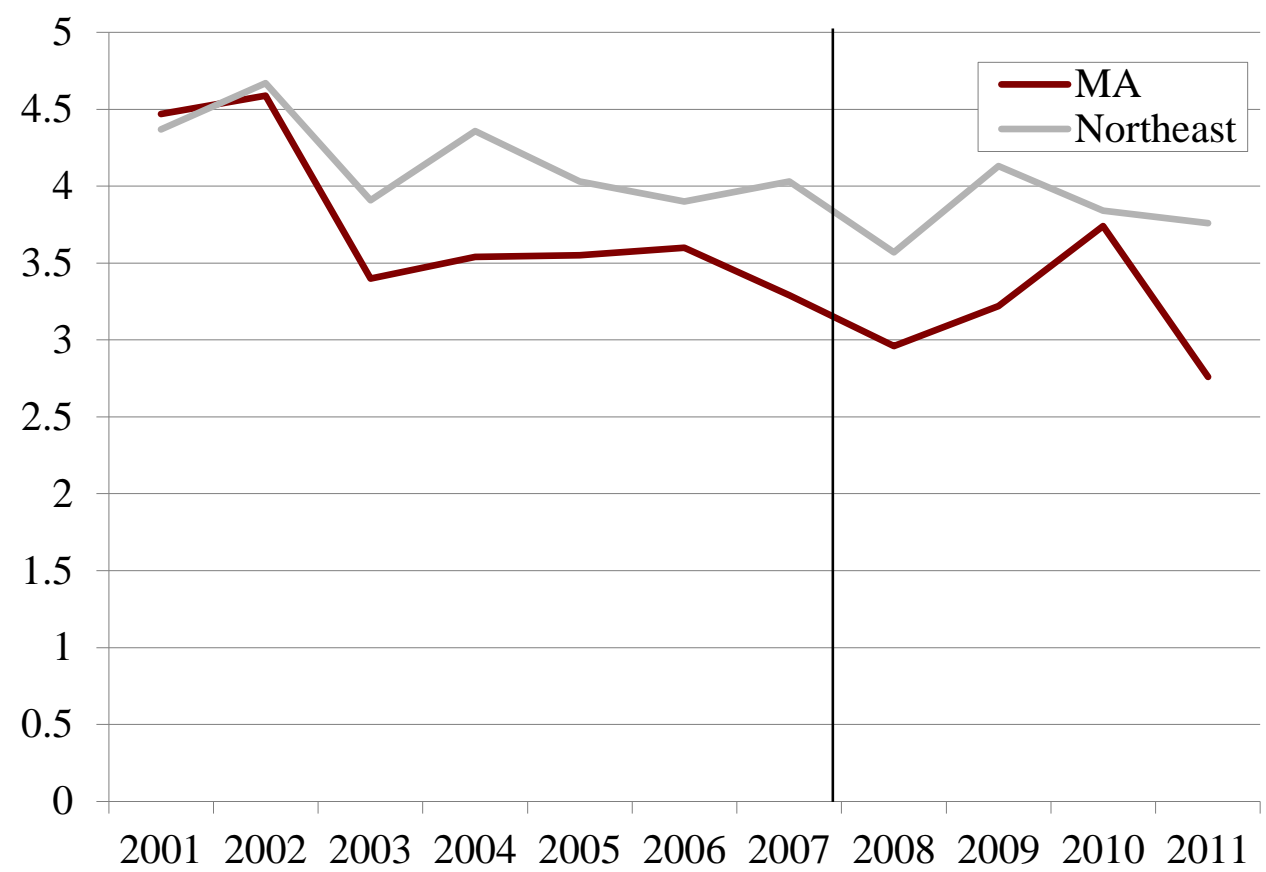

Source: Continuous Work History Sample-Longitudinal Employee-Employer Data merged file, 2000-2011. 
Table A1. Trends in Employment Outcomes before Massachusetts Health Insurance Reform, 2000-2006

\begin{tabular}{lcccc}
\hline & $\begin{array}{c}\text { Changing } \\
\text { employers }\end{array}$ & Large to small & Small to large & $\begin{array}{c}\text { Exiting } \\
\text { employment }\end{array}$ \\
\hline Age 30-54 & & & & \\
Time trend & -0.382 & 0.098 & 0.269 & -0.026 \\
MA & $(0.250)$ & $(0.136)$ & $(0.155)$ & -0.072 \\
& 2.766 & 2.725 & -0.432 & -0.070 \\
MA x Time trend & $(2.601)$ & $(1.883)$ & $(1.306)$ & $(0.542)$ \\
& -0.191 & -0.047 & 0.069 & -0.050 \\
Constant & $(0.492)$ & $(0.368)$ & $(0.232)$ & $(0.097)$ \\
& $15.840^{* * *}$ & $16.010^{* * *}$ & $17.050^{* * *}$ & $3.318^{* * *}$ \\
N (unweighted) & $(1.256)$ & $(0.651)$ & $(0.849)$ & $(0.400)$ \\
R-squared & & & & \\
& 0.493 & 14 & 14 & 14 \\
Age 55-64 & & 0.570 & 0.340 & 0.277 \\
Time trend & $-0.285^{* *}$ & & & \\
& $(0.096)$ & $(0.139)$ & $(0.318)$ & $(0.037)$ \\
MA & $2.577^{*}$ & $4.138^{*}$ & -0.900 & -0.009 \\
& $(1.358)$ & $(1.901)$ & $(1.840)$ & $(0.384)$ \\
MA x Time trend & -0.175 & -0.294 & 0.470 & -0.0992 \\
& $(0.250)$ & $(0.373)$ & $(0.597)$ & $(0.0638)$ \\
Constant & $10.140^{* * *}$ & $15.550^{* * *}$ & $14.990^{* * *}$ & $4.522^{* * *}$ \\
& $(0.528)$ & $(0.782)$ & $(1.028)$ & $(0.215)$ \\
N (unweighted) & & & & 14 \\
R-squared & 14 & 14 & 0.385 & 0.673 \\
\hline
\end{tabular}

Note: Observations are weighted to reflect population in MA and control states in each year. ${ }^{* * *} \mathrm{p}<0.01,{ }^{* *}$ $\mathrm{p}<0.05, * \mathrm{p}<0.1$.

Source: Continuous Work History Sample-Longitudinal Employee-Employer Data merged file, 2000-2011. 


\section{RECENT WORKING PAPERS FROM THE CENTER FOR RETIREMENT RESEARCH AT BOSTON COLLEGE}

Work, Retirement, and Social Networks at Older Ages

Eleonora Patacchini and Gary V. Engelhardt, November 2016

Calculating Expected Social Security Benefits by Race, Education, and Claiming Age

Geoffrey T. Sanzenbacher and Jorge D. Ramos-Mercado, November 2016

Do Late-Career Wages Boost Social Security More for Women than Men?

Matthew S. Rutledge and John E. Lindner, November 2016

Cognitive Impairment and Social Security's Representative Payee Program

Anek Belbase and Geoffrey T. Sanzenbacher, November 2016

How Would Reducing the Price of Older Workers Improve Labor Market Outcomes by Socioeconomic Status? Evidence from Health Insurance Premium Restrictions

Matthew S. Rutledge and Caroline V. Crawford, October 2016

An Overview of the Pension/OPEB Landscape

Alicia H. Munnell and Jean-Pierre Aubry, October 2016

What Are the Effects of Doubling Up on Retirement Income and Assets?

Deirdre Pfeiffer, Katrin B. Anacker, and Brooks Louton, September 2016

How Does Student Debt Affect Early-Career Retirement Saving?

Matthew S. Rutledge, Geoffrey T. Sanzenbacher, and Francis M. Vitagliano, September 2016

The Labor Supply of Disabled Veterans: 1995-2014

Matthew S. Rutledge, Geoffrey T. Sanzenbacher, and Caroline V. Crawford, August 2016

The Mortality Effects of Retirement: Evidence from Social Security Eligibility at Age 62 Maria D. Fitzpatrick and Timothy J. Moore, August 2016

How Would Investing in Equities Have Affected the Social Security Trust Fund?

Gary Burtless, Anqi Chen, Wenliang Hou, Alicia H. Munnell, and Anthony Webb, July 2016

Are Early Claimers Making a Mistake?

Alicia H. Munnell, Geoffrey T. Sanzenbacher, Anthony Webb, and Christopher M. Gillis, July 2016

All working papers are available on the Center for Retirement Research website (http://crr.bc.edu) and can be requested by e-mail (crr@bc.edu) or phone (617-552-1762). 